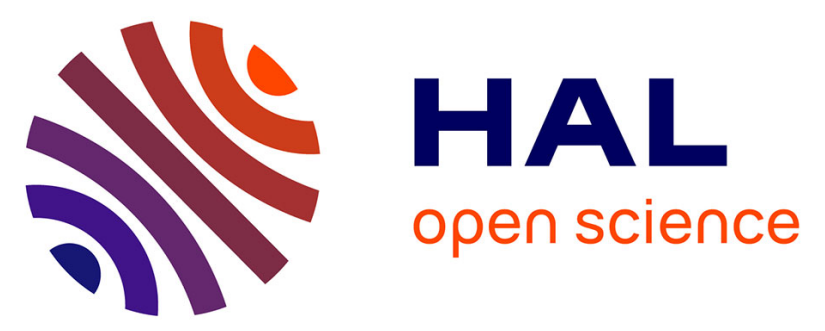

\title{
Sediment redox tracers in Strait of Georgia sediments - can they inform us of the loadings of organic carbon from municipal wastewater?
}

R.W. Macdonald, S.C. Johannessen, C. Gobeil, C. Wright, B. Burd, A. van Roodselaar, T.F. Pedersen

\section{To cite this version:}

R.W. Macdonald, S.C. Johannessen, C. Gobeil, C. Wright, B. Burd, et al.. Sediment redox tracers in Strait of Georgia sediments - can they inform us of the loadings of organic carbon from municipal wastewater?. Marine Environmental Research, 2008, 66, 10.1016/j.marenvres.2008.08.001 . hal00563047

\section{HAL Id: hal-00563047 https://hal.science/hal-00563047}

Submitted on 4 Feb 2011

HAL is a multi-disciplinary open access archive for the deposit and dissemination of scientific research documents, whether they are published or not. The documents may come from teaching and research institutions in France or abroad, or from public or private research centers.
L'archive ouverte pluridisciplinaire HAL, est destinée au dépôt et à la diffusion de documents scientifiques de niveau recherche, publiés ou non, émanant des établissements d'enseignement et de recherche français ou étrangers, des laboratoires publics ou privés. 


\section{Accepted Manuscript}

Sediment redox tracers in Strait of Georgia sediments - can they inform us of the loadings of organic carbon from municipal wastewater?

R.W. Macdonald, S.C. Johannessen, C. Gobeil, C. Wright, B. Burd, A. van Roodselaar, T.F. Pedersen

PII:

S0141-1136(08)00195-5

DOI:

10.1016/j.marenvres.2008.08.001

Reference:

MERE 3277

To appear in:

Marine Environmental Research

Received Date:

15 November 2007

Revised Date:

23 July 2008

Accepted Date:

4 August 2008

Please cite this article as: Macdonald, R.W., Johannessen, S.C., Gobeil, C., Wright, C., Burd, B., van Roodselaar, A., Pedersen, T.F., Sediment redox tracers in Strait of Georgia sediments - can they inform us of the loadings of organic carbon from municipal wastewater?, Marine Environmental Research (2008), doi: 10.1016/j.marenvres. 2008.08.001

This is a PDF file of an unedited manuscript that has been accepted for publication. As a service to our customers we are providing this early version of the manuscript. The manuscript will undergo copyediting, typesetting, and review of the resulting proof before it is published in its final form. Please note that during the production process errors may be discovered which could affect the content, and all legal disclaimers that apply to the journal pertain. 
1 Sediment redox tracers in Strait of Georgia sediments - can they inform us of the loadings of organic carbon from municipal wastewater?

3

\author{
Macdonald $^{1 *}$, R.W., S.C. Johannessen ${ }^{1}$, C. Gobeil ${ }^{2}$, C. Wright ${ }^{1}$, B. Burd ${ }^{3}$, A. van Roodselaar ${ }^{4}$ \\ and T.F. Pedersen ${ }^{5}$. \\ ${ }^{1}$ Department of Fisheries and Oceans, Institute of Ocean Sciences, PO Box 6000, Sidney, BC, \\ V8L 4B2, Canada
}

${ }^{2}$ Centre Eau, Terre et Environnement, Institut national de la recherche scientifique, Université du Québec, 490 de la Couronne, Québec (QC), G1K 9A9, Canada

${ }^{3}$ Ecostat Research Ltd., 1040 Clayton Rd., N. Saanich, B.C., Canada, V8L 5P6

${ }^{4}$ Metro Vancouver, 4330 Kingsway, Burnaby, B.C., Canada, V5H 4G8

University of Victoria, Elliott 166, PO Box 3055 STN CSC, Victoria, BC, Canada, V8W 3P6

* Corresponding author tel (250) 363-6409, fax (250) 363-6310, macdonaldrob@ pac.dfo-

\section{Abstract}

Organic carbon composition and redox element (Mn, Cd, U, Re, Mo, $\Sigma \mathrm{S}, \mathrm{AVS}$ ) distributions are examined in seven ${ }^{210} \mathrm{~Pb}$-dated box cores collected from the Strait of Georgia, British Columbia to evaluate the potential for redox elements to reveal impacts of anthropogenic loadings of labile organic carbon to sediments. In particular, the cores have been collected widely including regions far from local anthropogenic inputs and from locations within the zone of influence of two municipal outfalls where sediments are exposed to enhanced organic loadings from outfalls. We find a wide natural range in organic carbon forcing within the basin sediments generally reflected 
as $\mathrm{Mn}$ enrichments near the surface in cores exhibiting slow organic oxidation and sulphide, $\mathrm{Cd}$, Re, Mo, $\mathrm{U}$ and Re enrichments in cores exhibiting higher organic oxidation rates. Concentration profiles for redox elements or organic carbon are misleading by themselves, as they are influenced strongly by sediment porosity and sedimentation rate, and the organic matter remaining in sediment cores is predominantly recalcitrant. Fluxes of redox elements together with rates of organic metabolism estimated from sedimentation rates provide a better picture of the organic forcing. One core, GVRD-3, collected within the zone of influence of the Iona municipal outfall $(0.5 \mathrm{~km}$ away), exhibits the highest organic carbon oxidation rates, enhanced Ag fluxes in the sediment surface mixed layer and altered $\delta^{15} \mathrm{~N}$ composition, all of which implicate outfall particulates. Cd is also elevated in the GVRD-3 surface sediments, but evidence points to contamination and not redox forcing supporting this observation. Uranium also shows enrichment at sites near the outfalls, possibly in response to enhanced microbial metabolism. Predominantly these cores exhibit a wide natural range of organic carbon fluxes and organic carbon oxidation rates, supported by fluxes of marine and terrigenous organic carbon, within which it is difficult to identify any significant impact from municipal outfall organic carbon. Keywords: acid volatile sulphide, municipal outfalls, organic carbon, redox elements

\section{Introduction}

Hypoxic or anoxic conditions caused by nutrient and organic loading have long been considered among the most pressing problems for coastal seas (GESAMP, 1990; Diaz and Rosenberg, 1995; Cloern, 2001; Gilbert et al., 2005; Schiedek et al., 2007) and oxygen demand from an accumulated organic carbon sediment inventory may play a crucial role in sustaining hypoxic conditions in bottom waters (Turner et al., 2008). Oxygen drawdown to the point of anoxia occurs naturally in marine sediments where metabolizable carbon fluxes exceed the flux of oxygen into the sediments (Gobeil et al., 2001). Natural organic loadings to coastal sediments derive from marine primary production and associated vertical flux of metabolizable material, and from terrestrial loadings from rivers and coastal erosion. Added to these natural organic sources are anthropogenic loadings of organic-rich effluent from, for example, municipal outfalls 
and pulp and paper mills, and nutrients, which may enhance marine primary production and vertical flux (eutrophication).

An important question for the management of coastal resources is how much impact the anthropogenic loadings might have on the natural coastal OC cycle. In particular, regulators need to know whether or not hypoxic or anoxic tipping points are crossed due to augmented organic fluxes such that benthic or pelagic habitat becomes eliminated for biota requiring sustained oxygen supply above some minimum concentration. Impacts of organic loadings might be restricted to an area within tens of meters of a small point source or, in a more extreme case like the Mississippi Estuary, could involve over 20,000 $\mathrm{km}^{2}$ (Turner et al., 2008). Traditionally, an evaluation of the scale of the threat of individual or collective anthropogenic loadings may be estimated by comparing these with natural loadings through the construction of regional OC budgets. For the Strait of Georgia, in British Columbia, Canada, Johannessen et al. (2003) ranked particulate organic carbon (POC) sources as 1) primary production (285 kT/yr), 2) Fraser and other rivers (220 kT/yr), ocean dumping (14 kT/yr), municipal outfalls (12 kT/yr), pulp mills $(<8.5 \mathrm{kT} / \mathrm{yr})$ and aquaculture $(2 \mathrm{kT} / \mathrm{yr})$. Clearly, these estimates indicate that direct anthropogenic POC loadings are small $(<5 \%)$ compared to primary production and inputs from rivers at the scale of the greater Strait of Georgia. Likewise, an evaluation of nitrate budgets (Mackas and Harrison, 1997) suggests that the Strait of Georgia is naturally well supplied with nutrients and that loadings from municipal outfalls can play but a minor role $(\sim 7 \%)$, insufficient to produce large-scale organic loading that would draw down oxygen.

Loadings from outfalls into dynamic coastal waters are notoriously difficult and expensive to track as plumes that vary in time and space. In contrast, sediments often record the local integrated impact of particulate material settling to the bottom in patterns that makes stochastic sense (e.g., see Gearing et al., 1991; Gordon, 1997; Gobeil, 1999; Bennett and Metcalfe, 2000). In the Strait of Georgia, sediments have been shown to provide useful temporal records for metals and components of organic carbon (Macdonald et al., 1991; Gordon, 1997; Yunker et al., 1999; Johannessen et al., 2003; Johannessen et al., 2005a), pulp mill contaminants (Macdonald et al., 1992) and specific elements and compounds known to pass through municipal outfalls (Gordon, 1997; Shang et al., 1999; Johannessen et al., 2008). However, there is a problem in using the sediment record of bulk OC to assess the impact of anthropogenic OC loadings to sediments; the 
OC sediment record misses labile OC that has been oxidized, and it is this portion of OC that is of interest from the perspective of oxygen depletion.

It is well known that several elements, including $\mathrm{Mn}, \mathrm{Re}, \mathrm{Cd}, \mathrm{Mo}, \mathrm{U}, \mathrm{P}$ and Fe respond to redox conditions in sediments by dissolving or precipitating (e.g., Pedersen et al., 1989; Sundby et al., 1992; Rosenthal et al., 1995; Gobeil et al., 1997; Thomson et al., 2001; McKay et al., 2007). The distributions of redox elements in sediments are, accordingly, strongly controlled by the distribution of dissolved oxygen $\left(\mathrm{O}_{2}\right)$ and sulphide $\left(\mathrm{S}^{2-}\right)$, which are in turn controlled by the relative rates of organic metabolism and oxygen supply (Sundby, 2006). Therefore, redox elements respond to, and potentially record, the intensity of OC oxidation in sediments.

In this paper, we use seven ${ }^{210} \mathrm{~Pb}$-dated sediment box cores collected at widely-distributed locations in the Strait of Georgia (Fig. 1) to evaluate the current status of natural and anthropogenic organic loadings to sediments. The Metro Vancouver (formerly Greater Vancouver Regional District), consists of 8 urban cities: Cities of Vancouver, Burnaby, Coquitlam, Richmond, North Vancouver, Surrey and New Westminster), with a 2006 population estimate of just over 2 million. There are five wastewater treatment plants, but only two discharge directly into the marine environment, the Iona WWTP and the Lions Gate WWTP, both of which have primary treatment only. At Iona, twin discharge pipes extend $7.5 \mathrm{~km}$ onto the seabed of the Strait of Georgia, and the present discharge system came online in April of 1988, prior to which discharge occurred across the intertidal zone since the late 1950s. The mean daily flow (1997 - 2006) is 535 - 617 million litres per day. Lions Gate began discharge in 1961 and has been expanded seven times. The average daily flow rate (1997-2006) is 90-110 million litres per day.

Here, we examine OC profiles and inventories in sediments to evaluate burial and metabolism of carbon and set this against the distributions, inventories and fluxes of redox markers (Mn, Mo, $\mathrm{Cd}, \mathrm{Re}$, acid volatile sulphide (AVS) and total $\mathrm{S}(\Sigma \mathrm{S})$ ) within the sediments. The box cores have been collected widely from locations known to receive particulate material of municipal outfall origin and from more distant locations that are likely to receive most of their organic input from other sources, with only minor amounts of outfall particulates.

\section{Methods}




\subsection{Sediment core collection}

Seven sediment cores ( 45-56 cm in length) were collected in 2003 and 2004 from the central and northern Strait of Georgia (Table 1; Fig. 1) using a Pouliot box corer $(20 \mathrm{~cm} \times 30 \mathrm{~cm})$. Based on Ag as an indicator of sewage inputs (Sañudo-Wilhelmy and Flegal, 1992; Gobeil, 1999), we used the surface sediment map of Ag concentration produced by Gordon (1997) (Fig. 2) together with the nonylphenol ethoxylate map constructed by Shang et al. (1999) to select coring locations within the direct influence of municipal outfall particulates (GVRD-2, -3, and 4), and cores distant from such influence (GVRD-1, 5, 6, 7). GVRD-3 was located $0.5 \mathrm{~km}$ north of the Iona Island outfall, which has its diffuser section of pipe extending between the 60 and 90 m isobaths, while GVRD-2 was located almost equidistant $(\sim 13 \mathrm{~km})$ from the Lions Gate and Iona Island outfalls (Fig. 2). GVRD-2 is also located at the entrance to Burrard Inlet and therefore closest to industrial and municipal sources of organic matter (OM) broadly entering from the Vancouver region (e.g., see Yunker et al., 1999). Immediately upon recovery, the cores were sectioned for analysis into $1 \mathrm{~cm}$ intervals for the top $10 \mathrm{~cm}, 2 \mathrm{~cm}$ intervals for the next 10 $\mathrm{cm}$ and $5 \mathrm{~cm}$ intervals for the remainder of the core. At the time of sub-sectioning, samples were taken for a variety of analyses including radio-dating, organic content, metals and contaminants. Detailed sample collection and treatment, and analytical methods and data for a wide range of chemical parameters are given by Wright et al. (2008) and only brief descriptions of methods relevant to this paper are summarized below.

\subsection{Sediment dating}

A sub-sample from each depth interval was analyzed for ${ }^{210} \mathrm{~Pb}$ and ${ }^{226} \mathrm{Ra}$ (counting errors $<3 \%$ ) for dating; see Johannessen et al. (2005a; 2008). The activity of supported ${ }^{210} \mathrm{~Pb}$ was determined as the average of the ${ }^{226} \mathrm{Ra}$ activity measured at three depths (top, middle, bottom). A surface mixed layer (SML) was evident in all cores and each core was modeled for mixing and sedimentation rate using the advective-diffusive equation of the form:

$\mathrm{w}_{\mathrm{s}} \partial\left[{ }^{210} \mathrm{~Pb}\right] / \partial \mathrm{t}=\partial / \partial \mathrm{z}\left(\mathrm{D}_{\mathrm{B}} \partial\left[{ }^{210} \mathrm{~Pb}\right] / \partial \mathrm{z}\right)-\lambda\left[{ }^{210} \mathrm{~Pb}\right]$ $-1-$

where $\mathrm{w}_{\mathrm{s}}$ is the sedimentation velocity $(\mathrm{cm} / \mathrm{yr}),{ }^{210} \mathrm{~Pb}$ is the unsupported activity, $\mathrm{z}$ is depth in sediments, $\lambda$ is the ${ }^{210} \mathrm{~Pb}$ decay constant $\left(0.0311 \mathrm{yr}^{-1}\right)$, and $\mathrm{D}_{\mathrm{B}}$ is the biomixing coefficient $\left(\mathrm{cm}^{2} \mathrm{yr}^{-}\right.$ $\left.{ }^{1}\right)$. Assuming steady state applies to supported ${ }^{210} \mathrm{~Pb}$ in sediments, the equation may be solved 
143

analytically, once the depth of the SML has been estimated from the ${ }^{210} \mathrm{~Pb}$ profile (Lavelle et al., 1985). Sedimentation parameters derived from the ${ }^{210} \mathrm{~Pb}$ profiles are listed in Table 2.

\subsection{Acid-volatile sulphide (AVS), sulphur and metals analyses}

AVS was determined on wet samples, using the protocol described by Allen et al. (1993). Briefly, sediments were acidified with hydrochloric acid, and the evolving sulfide was trapped in a sodium hydroxide solution and subsequently determined by colorimetric analysis. The analytical precision, determined by replicate analysis $(\mathrm{n}=5)$ of one sample, was $10 \%$ at a concentration of $0.2 \mu \mathrm{mol} \mathrm{g}^{-1}$ (dry weight).

Sediment sub-samples were freeze-dried and homogenized by grinding. Aliquots ( $250 \mathrm{mg})$ deposited in Teflon beakers were heated for one hour at approximately $100^{\circ} \mathrm{C}$ on a hot plate with $10 \mathrm{~mL}$ of $\mathrm{HNO}_{3}$, and then, after the addition of $4 \mathrm{~mL}$ of $\mathrm{HClO}_{4}$, for two supplementary hours. After cooling, $5 \mathrm{~mL}$ of $\mathrm{HF}$ were added to the mixtures to complete the digestion at room temperature for 15 hours. The acids were then evaporated to near dryness and the residue dissolved in $1 \mathrm{~mL}$ of concentrated $\mathrm{HNO}_{3}$ and diluted to $50 \mathrm{~mL}$. The solutions were then analyzed with both ICP-OES (Inductively Coupled Plasma-Optical Emission Spectrometry; Mn, S) and ICP-MS (Inductively Coupled Plasma-Mass Spectrometry; Ag, Cd, Mo, Re, and U) using external calibrations. The precision ( \pm standard deviation) and accuracy (SRM value minus sample mean) of the analyses were determined by replicate analysis $(\mathrm{n}=5)$ of the standard reference sediments PACS-2 ( $\mathrm{Ag}- \pm 4.7 \%,-6 \%$; $\mathrm{Cd}- \pm 4.9 \%, 12 \%$; $\mathrm{Mn}- \pm 3.5 \%,-6.3 \%$; $\mathrm{Mo}-$ $\pm 4.8 \%,-11 \%$; $\operatorname{Re}- \pm 2.1 \%$, nd; $\mathrm{U}- \pm 7.0,4.7 \% ; \Sigma \mathrm{S}- \pm 1.4 \%,-8.9 \%$. Results obtained for S may underestimate $\Sigma$ S since a portion of the reduced S (AVS) might have been lost during the digestion procedure. However, it is likely that the use of nitric acid for the digestion limits that lost by oxidizing the sulphide to sulphate.

\subsection{Carbon and nitrogen analyses}

Carbon and nitrogen were analysed in the sediment core samples using the method of Calvert et al. (1995) in which OC is calculated as the difference between total carbon and carbonate carbon. Total carbon is measured by combustion and gas chromatography in a CHS analyzer and carbonate carbon by coulometry (precision $\pm 1.6 \%(\mathrm{sd})$ ). Stable isotopic composition $\left(\delta^{13} \mathrm{C}\right.$, 
$172 \delta^{15} \mathrm{~N}$ ) was analyzed for all core sections at the University of British Columbia using the methods

173 reported by Calvert et al.(2001). In this paper we use the terms organic matter (OM) to refer to

174 all organic components (e.g., C, N, O, H), and organic carbon (OC) to refer specifically to the

175 carbon component of OM.

\section{2.5. Organic matter composition as a tracer of sources}

177 Sources of OM in the Strait of Georgia have previously been inferred from the stable isotopic 178 composition $\left(\delta^{13} \mathrm{C}, \delta^{15} \mathrm{~N}\right)$ and $\mathrm{C} / \mathrm{N}$ ratio (Macdonald et al., 1991; Calvert et al., 2001;

179 Johannessen et al., 2005b) using simple algebraic equations and assumptions of representative 180 end member composition. Specifically;

184 where the subscripts refer to terr - terrigenous, mar - marine, and obs - observed. Following

185 Macdonald et al. (1991) we use here the following values; $\mathrm{C} / \mathrm{N}$ marine $=6.2, \mathrm{C} / \mathrm{N}$ terrestrial $=90$, $\delta^{13} \mathrm{C}$ marine $=-19.7 \%$ o, $\delta^{13} \mathrm{C}$ terrestrial $=-25.0 \%$.

187 Likewise, $\delta^{15} \mathrm{~N}$ has been applied in marine systems, even deep-ocean ones, to infer whether or not OM contains nitrogen from sewage sources (Van Dover et al., 1992). For this sort of simple estimate, two sources, municipal and natural, are assumed to comprise the observed OM;

192 where the subscripts refer to: mun - municipal, nat - natural, and obs - observed. To make

193 quantitative estimates of source then requires an assumption of the $\delta^{15} \mathrm{~N}$ appropriate to sewage,

194 which may vary from location to location and which also varies with trophic level. For the west195 coast outfalls in California, measurements place $\delta^{15} \mathrm{~N}$ at $1.8 \%$ o to 2.5\%o (Sweeney and Kaplan, 196 1980; Spies et al., 1989). In the Strait of Georgia, however, based on a single point of 1.6\%o, 197 Johannessen et al. (2005b) suggested that the Fraser River may also deliver OM with low $\delta^{15} \mathrm{~N}$

198 signature. The Fraser River source, itself, although likely dominated by natural organic material, 199 may also contain nitrogen from agricultural sources including nitrogen-containing fertilizers (- 
$1.5 \%$ - $-0.6 \%$ ) and poultry manure $(8 \% o-16 \%$ ) (Wassenaar, 1995).

\subsection{Estimation of elemental inventories and fluxes in sediment cores}

The enrichment of redox markers in the GVRD cores has been quantified as inventories (Table 3) by integrating the amount of each element above an assumed detrital background (the lowest values found at the bottom of the core or in the Strait of Georgia) following the same method used by Sundby et al. (2004). As noted by Sundby et al. (2004), this process does not assume that elemental accumulation has been constant, nor does it account for any continued enrichments below the depth of the core $(45-55 \mathrm{~cm})$.

\section{Results}

\subsection{Sedimentation rates, surface mixing and geochemical setting}

Sedimentation velocities varied from $0.25 \mathrm{~cm} \mathrm{yr}^{-1}$ (based on compaction at the bottom of the core, 40-50cm depth) in the northern Strait at GVRD-1 to $2.9 \mathrm{~cm} \mathrm{yr}^{-1}$ at GVRD-6, which is located toward the southern end of the Strait (Table 2, Fig. 3). In the GVRD-4 core the ${ }^{210} \mathrm{~Pb}$ profile was noisy and without any significant trend, likely implying a very rapid sedimentation rate given its location (e.g., see Hart et al., 1998). The sedimentation rates for this set of cores are generally high near the mouth of the Fraser and decrease with distance from the delta. This pattern follows that observed for previous core collections (see, Johannessen et al., 2003; Johannessen et al., 2005a) and stratigraphies based on seismic surveys (Hart et al., 1998). Most of the sediment cores exhibit surface mixed layers (SMLs) of 7-12 cm (Fig. 3) and, in general, higher mixing rates are associated with higher sedimentation rates (Table 2). The fluxes of excess ${ }^{210} \mathrm{~Pb}$ (Table 2) fall within ranges observed previously in the Strait of Georgia (Macdonald et al., 1991; Johannessen et al., 2003; Johannessen et al., 2005a) with the exception of the very high flux at GVRD-6, which was not unexpected given the high vertical flux captured by sediment traps near that location (Johannessen et al., 2005b) and evidence of year-round recirculation and trapping of particles resuspended by tidal currents in the passages to the south (Johannessen et al., 2006).

\subsection{Ag and the influence of municipal outfall particulates}

As noted above, we used the distribution of $\mathrm{Ag}$ in surface sediments determined by Gordon 
(1997) in the mid 1990s to place several of our cores within the likely zone of impact of municipal outfall particulates (Fig. 2). Silver provides an excellent tracer in the proximity of municipal outfalls because natural crustal and sedimentary concentrations are low compared to municipal effluent (Table 3, Sañudo-Wilhelmy and Flegal, 1992). The vertical profiles for Ag in the GVRD cores (Fig. 2; panels) show that, as expected, GVRD-2, -3 and -4 contain significant enrichments of Ag above the Strait of Georgia background (0.1-0.2 $\left.\mu \mathrm{g} \mathrm{g}^{-1}\right)$ in the top $30 \mathrm{~cm}$ of the core consistent with outfall loadings. Surprisingly, GVRD-1, which is distant from all outfalls, also shows a clear enrichment of Ag in the top $25 \mathrm{~cm}$. However, this enrichment likely does not derive directly from outfall particulates as will be discussed later.

Based on the excess Ag inventories above background deep in the sediment cores (Table 3), GVRD-3 $\left(14.2 \mu \mathrm{g} \mathrm{cm}^{-2}\right)$ is most strongly influenced by outfall particulates, followed by GVRD-2 $\left(6.6 \mu \mathrm{g} \mathrm{cm}^{-2}\right)$ and, possibly, GVRD-4 $\left(1.1 \mu \mathrm{g} \mathrm{cm}^{-2}\right)$.

\subsection{Redox markers (Mn, AVS, $\Sigma S, C d, M o, U, R e)$}

All cores except GVRD-7 show relatively constant Mn concentrations below the SML (Fig. 4), indicative of the local mineral background concentration (Dunn, 1998), with values ranging from 400 to $600 \mu \mathrm{g} \mathrm{g}^{-1}$. Near the sediment surface, several of the cores show evidence of $\mathrm{Mn}$ enrichment. GVRD-5 exhibits the best-developed Mn-enriched layer, confined mostly to the top $2 \mathrm{~cm}$. Higher Mn concentrations deep in this core may signal a slight preserved enrichment of Mn (possibly as carbonate (Calvert et al., 2001)). GVRD-1, -6 and -7 also show slight Mn enrichments in the top 3-5 cm. GVRD-2 shows a very minor enrichment in the top $10 \mathrm{~cm}$, but the average Mn concentration (537 $\pm 3 \mu \mathrm{g} \mathrm{g}^{-1}$ (SE)) is consistent with the low crustal average for granite (Taylor, 1964; Borchers et al., 2005). GVRD-3 shows no detectable enrichment, with surface values actually depressed $\left(498 \pm 5 \mu \mathrm{g} \mathrm{g}^{-1}\right)$ relative to deeper layers of the core $(540 \pm 6 \mu \mathrm{g}$ $\left.\mathrm{g}^{-1}\right)$. Finally, GVRD-4 is noisy toward the surface, making choice of background difficult, but the profile implies that little, if any, excess Mn resides at this site.

The concentration of AVS varies widely among the cores (Fig. 4). The lowest values are found concentrations remain low throughout the core but at all other sites they tend to increase with depth. GVRD-3 and -5 exhibit a pronounced rise with depth in the top 5 to $15 \mathrm{~cm}$; GVRD-2, -4 
and -6 show a more gradual concentration increase with depth in the core.

$\Sigma \mathrm{S}$ (Fig. 4) shows background values of about $2000 \mu \mathrm{g} \mathrm{g}^{-1}$ which are comparable to $1724 \mu \mathrm{g} \mathrm{g}^{-}$ ${ }^{1}$, the median determined for Strait of Georgia surface sediments by Dunn (1998). Most of the cores show excess $\Sigma$ S enrichments below the SML, especially in GVRD-1 and -7. For GVRD-1 and -2, the AVS concentrations are $<10 \%$ of the excess $\Sigma$ S concentration, but they are equivalent to about half those of excess $\Sigma \mathrm{S}$ in the other cores, omitting GVRD-7 where AVS data are not available.

Almost all cores show Cd increasing with depth in the core (Fig. 4). The obvious exception, GVRD-3, has a marked surface enrichment in the top $15 \mathrm{~cm}$. For all of the other cores, the lowest $\mathrm{Cd}$ values near the core surfaces fall within the range expected for crustal rocks. The highest concentrations of Cd are found in GVRD-1 followed by GVRD-3, -6, and -2. GVRD-4 and -7 have similar, low Cd concentrations below $5 \mathrm{~cm}$ with slight enrichments near the surface. GVRD-5 has low Cd concentrations throughout the profile.

Molybdenum mimics Cd to a degree in that there are increases in Mo with depth in most of the GVRD cores (Fig. 4). We see little evidence of surface enrichment of Mo in association with Mn enrichment as observed in the Gulf of St Lawrence (Sundby et al., 2004) (cf. profiles for GVRD5 and 7). In deep sediments, the highest Mo concentrations are observed at GVRD-1 and -5, with $-7-3,-4$ overlapping each other in the middle, and then GVRD-2 and -6 exhibit the lowest concentrations. The prominent peak in Mo between 10 and $25 \mathrm{~cm}$ in GVRD-7 is paralleled by $\mathrm{U}$ and Re (Fig. 4) and also corresponds with a depression in the excess ${ }^{210} \mathrm{~Pb}$ profile (Fig. 3). GVRD-6, -2 and -1 all exhibit smooth profiles compared to the other cores.

Uranium is clearly enriched at GVRD-1 (Fig. 4; note scale changes between U panels). Lesser enrichments are evident in GVRD-2 and -3 with all three of these enriched cores showing increases in $U$ with depth. The remaining cores show slight increases with depth, and the lowest surface values range from 1.1 to $1.2 \mu \mathrm{g} \mathrm{g}^{-1}$. GVRD-7 exhibits a U peak between 10 and $25 \mathrm{~cm}$. Rhenium profiles parallel the U profiles (Fig. 4). GVRD-1 is exceptional in having much higher concentrations than all the other cores (Fig. 4; note scale change between GVRD-1 and the other cores). In this core, Re increases down to about mid core and remains constant thereafter. The other core that exhibits an unusual feature is GVRD-7, where there is a marked peak in Re 
between about 10 and $25 \mathrm{~cm}$. Otherwise, Re profiles tend to be smooth, and the concentrations range by only a factor of about 2 .

\subsection{Organic matter}

Organic carbon in the sediment surface varies from greater than $4 \%$ in northern Strait at GVRD-1 to less than 1\% at GVRD-4 off the mouth of the Fraser River (Fig. 3). Most of the cores exhibit OC concentrations in the $0.5-2 \%$ range, similar to the range observed previously in the central Strait by Johannessen et al. (2003). GVRD-1, at 3-4\% OC, is anomalously high, though similar to the surface values measured in cores collected previously in the northern Strait (3.64 and $5.02 \%$, Johannessen et al., 2003). Bornhold (1978), who surveyed surface sediments from the northern Strait of Georgia, reported all values $<3.5 \%$ (using a loss on ignition method). All cores exhibit OC oxidation as evidenced by decreases in \%OC with depth in the core. To quantify the loss of OC in accumulating sediments, the $\%$ OC in the incident flux was modelled assuming that, in the absence of bioturbation, the concentration of organic $\mathrm{C}$ would decrease with depth at a first order rate and, based on the OC profile in each core, that at some depth the metabolism of carbon dropped to near zero with burial occurring below that depth (Table 4). Carbon fluxes could not be calculated for core GVRD-4 due to the difficulty of estimating sedimentation rate from the excess ${ }^{210} \mathrm{~Pb}$ profile, and it is not clear that core GVRD-4 reaches a burial depth, so calculated values for that core are uncertain. The organic burial rate is highest at GVRD-6, -3 and -5 and lowest at GVRD-1 despite the high \%OC content. Noteworthy are the implied high OC oxidation rates occurring at GVRD-3 and GVRD-6.

The average composition of $\mathrm{OM}\left(\delta^{13} \mathrm{C}, \delta^{15} \mathrm{~N}, \mathrm{C} / \mathrm{N}\right.$ ratio $)$ in the GVRD cores varies systematically among cores (Table 5); sites near the Fraser River delta have higher C/N ratios, and lower $\delta^{13} \mathrm{C}$ and $\delta^{15} \mathrm{~N}$ compositions signalling larger proportions of terrestrial OM. Vertical profiles for these parameters (not shown) generally exhibit negligible trends with depth, as apparent from the relatively small standard errors (SEs). Notable exceptions are GVRD-1, where $\delta^{13} \mathrm{C}$ is constant at $-20.5 \%$ deep in the core but then from 20 to $10 \mathrm{~cm}$ decreases to $\sim-21.5 \%$, and GVRD-3, where $\delta^{15} \mathrm{~N}$ is almost $4 \%$ o deep in the core but then from 14 to $10 \mathrm{~cm}$ decreases to 2.7\%o. The uniform vertical distribution of $\delta^{15} \mathrm{~N}$ in most cores together with the higher values $(5.1-6.5 \%$ ) in the distal and basin locations, imply that much of the OM metabolism has 
occurred in oxic conditions and that anoxic metabolism of the nitrogen part of the OM, which would lead to lower $\delta^{15} \mathrm{~N}$ values, is minimal (Lehmann et al., 2002). In Table 5, a breakdown of the average marine content of $\mathrm{OC}$ in these 7 sediment cores $\left(\mathrm{F}_{\mathrm{mar}}\right)$ is estimated as described in the methods using the end-member compositions listed in the footnote to the table. The results show that marine OC ranges from $52 \%$ to $75 \%$ of total OC, with the basin cores (GVRD-1, -5, -6, \& -7) generally exhibiting the higher values.

\section{Discussion}

\subsection{Application of redox elements to organic cycling in sediments}

Redox elements are delivered to sediments in several ways including as conservative elements in bottom water that diffuse into sediment because there is a sink created within the sediments by precipitation (e.g., Re, U, Mo, Cd). They may also enter the biological cycle in soft parts of plankton, exhibiting nutrient-like behaviour (e.g., Cd), or hard parts of diatoms (e.g., Ag) and settle to sediments in the vertical particle flux, or be scavenged to particles under oxic conditions (Mn) (e.g., see de Baar et al., 1994; Sundby et al., 2004; Flegal and Ranville, 2005).

In the present study, we are interested in finding out whether or not profiles of redox-sensitive elements in sediments can be used to identify recently-added organic loadings from point sources such as municipal outfalls. In principle, a sediment column achieves a steady-state balance in its redox elements that is controlled in the long term by the flux of metabolizable organic carbon to that site. This steady-state balance is, of course, subject to seasonal- and decadal-scale changes in organic loading which may cause redox boundaries to shift upward and downward over time (Gobeil et al., 2001; Sundby, 2006). Thus, the zonation in elements based on oxic, suboxic, sulphidic boundaries, would reflect the combination of conditions set by sedimentation rate, average labile organic loading, and sediment texture. Bottom dissolved oxygen conditions also play a role. Clearly, these characteristics vary widely within the Strait of Georgia as shown by the data assembled in Tables 2 and 4. The task of assessing added anthropogenic loadings must, therefore, be accomplished in consideration of the natural background of sediments, which varies considerably in the Strait of Georgia (Macdonald et al., 1991; Johannessen et al., 2003; Yunker 
and Macdonald, 2003; Johannessen et al., 2005b). Furthermore, the effect of added metabolizable carbon would not be the same among these sites considering that the vertical distribution of redox boundaries differs between sites, a circumstance that demands a site-specific consideration of whether or not additional organic carbon loading is causing change.

Oxidation of OC within the sediments is evident in many of the GVRD core profiles as a decreasing concentration of OC down core (Fig. 3). However, it is important to remember that fresh, labile OM may be metabolized rapidly in the SML such that it leaves no record at all in the OM sediment profiles. The amount and reactivity of OM reaching sediments varies with water depth (e.g., see Bishop, 1989; Johannessen et al., 2005b) and, although all sources of OC are metabolized to some degree in marine sediments, each source exhibits its own reactivity and metabolic efficiency (e.g., see Goñi et al., 2005). The average OC composition of incident sediment estimated from our sediment profiles (Table 4) is about $1.8 \%$ OC. This may be compared with average composition of settling particles caught in sediment traps deployed at 150-300 m water depth in the southern and central Strait for 2-3 years of $1.8 \%$ to $2.5 \%$ OC and at $150 \mathrm{~m}$ in the north-central Strait of 7.3\% OC (Johannessen et al., 2005b); sediment trap particulates on average contain higher \%OC than the particles entering the sediments below them.

The redox markers included here for examination (Mn, AVS, $\Sigma \mathrm{S}, \mathrm{Cd}, \mathrm{Mo}, \mathrm{U}, \mathrm{Re}$ ) respond variously to sedimentary redox conditions as described in numerous studies (e.g., see Klinkhammer and Palmer, 1991; Colodner et al., 1993; Rosenthal et al., 1995; Crusius et al., 1996; Morford et al., 2001; Sundby et al., 2004; McKay et al., 2007; Morford et al., 2007). Reduced manganese $\left(\mathrm{Mn}^{2+}\right)$ is soluble, whereas manganese oxides or hydroxides are solid precipitates. As a consequence of the banded zonation of oxygen sources in sediments undergoing diagenesis, when oxides of manganese are used to support OC metabolism, the reduced $\mathrm{Mn}^{2+}$ enters pore water and diffuses upward to re-precipitate when it meets oxygen.

The formation of AVS during early diagenesis is an unequivocal indicator of sulphate reduction; however, the interpretation of AVS profiles is fraught with difficulty due to dynamic reactions, methodological problems and the mixed set of components that actually make up AVS (Morse and Rickard, 2004). For AVS to accumulate, $\mathrm{O}_{2}, \mathrm{MnO}_{2}$, and $\mathrm{NO}_{3}{ }^{-}$in porewater must have been completely depleted, and pore water must contain, or have recently contained, 
sulphide. AVS, however, usually constitutes only a small part of the total sulphide $(<10 \%)$ and is ephemeral, often reaching a maximum at some depth within a sediment (Morse and Rickard, 2004; Sundby et al., 2004). Sulphidic conditions, indicated by the presence of AVS, imply that Cd will precipitate as CdS (Gobeil et al., 1987; Rosenthal et al., 1995; McKay et al., 2007). Furthermore, Mo, which is soluble under suboxic conditions, undergoes complex chemical reactions involving thiomolybdates (e.g., $\mathrm{MoS}_{4}{ }^{2-}$ ) in the presence of sulphide (Crusius et al., 1996; Erickson and Helz, 2000; Sundby et al., 2004), which lead eventually to Mo scavenging by pyrite (McKay et al., 2007). The precipitation of CdS and adsorption of Mo to pyrite within sediments then sets up porewater diffusion gradients for these elements with the rate of diffusion into sediments depending on the elemental concentration in bottom water and the depth in sediments (diffusion path length) at which precipitation is occurring; AVS/pyrite near the surface of the sediment implies a short diffusion path length and, therefore, rapid diffusion and rapid accumulation even in near-surface sediments (Pedersen et al., 1989). This simple picture is rendered considerably more complicated by potentially slow kinetics of a component of the precipitation process, as evidenced by continued increases in solid-phase concentrations of redox elements like Cd, Re, $\mathrm{U}$ and Mo with depth in at least the top $50 \mathrm{~cm}$ of many sediment cores (e.g., see Crusius and Thomson, 2000; Sundby et al., 2004, and Fig. 4). Total S, on the other hand, reflects the long-term capture of sulphides within sediments, including pyrite phases that do not dissolve under weak acid (Fig. 4). These phases become a long-term repository for redox metals that have either low sulphide solubility constants (e.g, $\mathrm{Cd}, \mathrm{Fe})$ or high adsorption coefficients (Mo).

Rhenium behaves differently than the redox sulphidophiles discussed above, in that it is mobilized in oxic sediments but can be fixed into the solid phase under suboxic conditions. The process of fixation, thought to involve reduction of $\operatorname{Re}(\mathrm{VII})$ to $\operatorname{Re}(\mathrm{IV})$ (Colodner et al., 1993), is reversible if oxic conditions return (Crusius and Thomson, 2000). Fixation of Re, therefore, precedes the fixation of Mo or Cd, which involve sulphides (Crusius and Thomson, 2000). Uranium also forms authigenic enrichments under suboxic conditions similar to those that sequester Re (Cochran et al., 1986).

In summary, the diffusion and authigenic accumulation of redox elements like $\mathrm{Cd}, \mathrm{Mo}, \mathrm{Re}$ and $\mathrm{U}$ from bottom water into sediments are controlled by redox conditions, which themselves are 
403

controlled by metabolizable OM. The length of the diffusion pathway between oxic bottom waters and suboxic or sulphidic pore waters in sediments, $\Delta \mathrm{z}$, will generally decrease with higher organic loadings because these move the oxic-suboxic-anoxic boundaries closer to the sediment surface. A shorter path implies higher flux but, in the case of slow precipitation kinetics, the diffusion path length can be considerably extended. Also of importance will be the sedimentation rate (slow rates imply higher build-up (Sundby et al., 2004)) and porosity (high porosity implies low fraction of solids on which the build-up occurs). Armed with this general understanding of redox behaviour of the above tracers, we now turn attention to the chemical profiles in the seven GVRD cores.

\subsection{GVRD-1}

This site, chosen as a distal background site for the study, is far from any marine outfall and over $100 \mathrm{~km}$ from the large outfalls at Vancouver. Therefore, the enrichment of $\mathrm{Ag}$ in this core (Fig. 2) is, at first glance, surprising. There are two potentially widespread sources of contaminant Ag to Strait of Georgia - municipal outfalls, and the Britannia Mine in Howe Sound (late 1800s - 1974), approximately $140 \mathrm{~km}$ away from GVRD-1 (Drysdale and Pedersen, 1992). Ag released via municipal outfalls or from mining activities is partly particulate and partly dissolved due to the formation of stable chloro-complexes in sea water, which favour the wider dispersal of Ag into the coastal sea (e.g., Luoma et al., 1995). Thus it is likely that over the past 50 years Ag loadings to the greater Strait of Georgia from municipal wastewater or other anthropogenic sources like the Britannia Mine, have augmented dissolved Ag concentrations above the pre-industrial background. These higher Ag concentrations have then been transmitted to basin water through mixing and vertical flux of, for example, the hard parts of diatoms which are known to sequester Ag (Flegal et al., 1995), and which also support much of the vertical flux in the central Strait (Johannessen et al., 2005b). At the sediment surface and within the sediments the silicate dissolves, releasing Ag, which may then diffuse into the sediment where it is immobilized in the anoxic zone (e.g., see Crusius and Thomson, 2003). Thus, the processes of vertical flux, mixing and sequestration of $\mathrm{Ag}$ in sediments by diffusion to a reduced sink, which support Ag enrichment at GVRD-1, occur without implying that reactive particulate OM from outfalls reaches the site. The general increase in Ag concentration toward the surface of GVRD-1 
implies that detectable Ag contamination throughout the Strait of Georgia commenced approximately 50-60 years ago, in about the same time frame as local contamination commenced in the near-field surrounding outfalls (Gordon, 1997). Note, however, that the inventory of excess Ag is much smaller at GVRD-1 than near the outfalls (Table 3).

The $\mathrm{Mn}$ and $\Sigma \mathrm{S}$ profiles imply that a full range of conditions exist in the sediment from oxic in the top few $\mathrm{cm}$ to sulphidic at depth. This core differs widely from all other cores in that it maintains high OC concentrations throughout, and exhibits almost no AVS build-up. The geochemical setting of this core is defined by low sedimentation rate (Table 2) and low OC oxidation rate (Table 4), which is manifest by sluggish biomixing. The maintenance of redox gradients in the core allows only a slow buildup in concentration of the suboxic-anoxic elements like Cd, Mo, $\mathrm{U}$ and Re relative to most other cores (Table 6). Judging this core solely by its elemental concentrations leads to a false impression that it is a more vigorous redox-sequestering site than most others: compare the GVRD-1 profiles for $\Sigma \mathrm{S}, \mathrm{Cd}, \mathrm{Mo}, \mathrm{U}$ and Re with those for the other cores in Fig. 4. The concentrations of Re and U are exceptionally high partly due to a high porosity (low solids concentration) and partly due to slow sedimentation rate, which allows a long time for element build-up. Likewise, $\mathrm{Cd}, \mathrm{Mo}$ and $\Sigma \mathrm{S}$ accumulate strongly in the solid phase, especially below the SML (7 cm) (Fig. 4). AVS may have been produced in this core, but due to the slow sedimentation rate, sufficient time has likely elapsed to convert it to forms not amenable to weak-acid leaching. As noted by Morse (2004), AVS exhibits extreme variability and is ephemeral, possibly because it exists in a dynamic state between production of iron sulphide mineral and its pyritization to forms not leached by weak acid.

This core certainly well illustrates the difficulty of assessing geochemical conditions in the sediment based solely on sediment concentrations or even concentration gradients. AVS does not appear to be a reliable indicator of the concentration of reduced elements, and certainly gives a different impression than $\Sigma S$ in this core. The OC profile in GVRD-1 (Fig. 3) shows that there is metabolizable carbon in the top 20-30 cm and this appears to maintain suboxic/anoxic conditions deep in the core, but according to Table 4 the inventory and OC oxidation rates are not exceptional. The high $\delta^{15} \mathrm{~N}$ suggests that most of the $\mathrm{OM}$ at this site is recalcitrant, having been degraded under oxic conditions (Lehmann et al., 2002) with ${ }^{14} \mathrm{~N}$ selectively removed during 
461

462

463

464

465

466

467

468

469

470

471

472

473

474

475

476

477

478

479

480

481

482

483

484

485

486

oxidation, and much of the degradation has probably occurred before the OM reached the sediment surface. The remaining, buried OM no longer contains much worth metabolizing or is, perhaps, protected by absorption onto fine mineral grains (Hedges and Keil, 1995). In keeping with the impoverished labile OM supply, this site also exhibits the lowest infaunal biomass of all core locations (Burd et al., submitted). Based on $\delta^{13} \mathrm{C}$ and $\mathrm{C} / \mathrm{N}$ ratios, GVRD-1 contains the largest proportion of marine OM among all cores (Table 5). Despite the difficulty of interpreting the bulk properties at this site, the OC oxidation rate, which is low, far better accounts for the relatively low rates of sequestration for redox elements (Table 6).

\section{3. $G V R D-2$}

This sediment core, which is located at the entrance to Burrard Inlet (Fig. 2), is potentially in the zone of influence of Lions Gate outfall (12.4 km to the east) and Iona Island outfall (14 km to the south) according to the excess Ag inventory (Table 3). The site, which is also potentially exposed to organic loadings and metals from several sources including Greater Vancouver (Yunker et al., 1999), the Fraser River and marine primary production (Table 5), shows no obvious signal in the OC profile or OM composition $\left(\delta^{15} \mathrm{~N}, \mathrm{C} / \mathrm{N}\right)$ that would definitively implicate outfall loadings, although it does exhibit the third highest OC metabolic rate and the largest inventory of metabolizable OC (Table 4). The small inventory of Mn near the surface (Table 3) suggests that oxygen penetration into the sediment is weak; Cd, Mo, U, $\Sigma \mathrm{S}$ and AVS all point to sulphidic conditions below the SML. The striking features in the redox markers for this core are the 'reverse' profiles for Re, which decreases with depth throughout the core, and U and Mo which also decrease with depth below the SML. Based on four sediment core profiles collected from the Gulf of St. Lawrence, analyzed in a very similar manner, Sundby et al. (2004) proposed that slow sequestration kinetics together with diffusion must be invoked to explain why elements like Cd, Re, Mo and U normally tend to increase with depth in sediments down to at least $50 \mathrm{~cm}$, and certainly we see the same sorts of increases in most of the other GVRD cores (Fig. 4).

We speculate that recent enhancement in the sequestration of $\mathrm{Re}, \mathrm{U}$ and Mo may have produced the reversed profiles in GVRD-2, which would imply a recent increase in labile OM 
loading. The most plausible source of such loading would be the Lions Gate outfall, which was constructed in 1966 and/or the Iona deep outfall constructed in 1988. These same OC loadings might also be invoked to explain part of the high inventory of metabolizable OC in this core, although the shallow water column also allows for higher natural marine OC fluxes. If increased OC loadings commencing in 1966 are the cause of the reversed profiles, then some portion of the dissolved Re, Mo and $\mathrm{U}$ must undergo reasonably rapid deposition in the top part of the core, and certainly more rapid than the slow sequestration proposed by Sundby et al. (2004) to explain deep core increases. The relatively large mixing rate in the SML (Table 2) further supports the notion that the sediments at GVRD-2 are actively foraged in response to metabolizable OM. Lovely et al. (1991) proposed that the sequestration of authigenic $U$ was mediated microbially; the high inventory and flux of $U$ (Tables 3 and 6) at GVRD-2 may, therefore, also be a product of the apparent availability of reactive OC at this site.

\section{4. $G V R D-3$}

From the perspective of identifying whether particulate organic matter (POM) from municipal outfalls can be detected in altered sediment diagenetic redox reactions, GVRD-3 clearly provides the best test case because it is located only $0.54 \mathrm{~km}$ north of the Iona Island diffuser, a region projected to experience maximum particulate deposition from the outfall plume (Hodgins and Hodgins, 2000, Fig. 1). The surface sediment Ag contours, the vertical profile and inventory for Ag (Fig. 2, Table 3), the $\delta^{15} \mathrm{~N}$ depression in the SML (Table 5), and the high OC flux strongly implicate recent additions of municipal POM. A quantitative estimation of the influence of municipal outfall particulates is difficult to make using only the $\delta^{15} \mathrm{~N}$ composition because of the variation within this core and among cores (Table 5). These variations imply that natural $\delta^{15} \mathrm{~N}$ derives from at least two different sources (marine (8-10\%o) and terrigenous (1.5-3\%o); and see Johannessen et al. (2005b); Calvert et al. (2001)). For GVRD-3, the shift in $\delta^{15} \mathrm{~N}$ in the top 15 $\mathrm{cm}$ of the sediments (Table 5) can be viewed as recently added loadings from the outfall to sediments that comprise a mixed terrigenous-marine nitrogen source.

The surface layers show no Mn enrichment, and the slightly lower concentrations in the SML $\left(498 \pm 5 \mu \mathrm{g} \mathrm{g}^{-1}\right)$ than deeper in the core $\left(540 \pm 6 \mu \mathrm{g} \mathrm{g}^{-1}\right)$ suggest that a recent increase in 
517 metabolizable OC loading may have driven $\mathrm{Mn}^{2+}$ out of the sediments (Fig. 4) or that there has 518 been recent increase in particle loadings from a source containing low Mn concentration. AVS 519 builds up quickly in this core suggesting that sulphide is produced within $1-2 \mathrm{~cm}$ of the sediment 520 surface (Fig. 4).

521 The only abnormal profile in the redox markers shown on Fig 4. for this core is Cd, which 522 shows a marked build-up within the SML (note that Ag also shows build-up in the SML (Fig. 2)). 523 There are two possible explanations for high Cd concentrations at the top of the GVRD-3, one being enhanced deposition of $\mathrm{Cd}$ as sulphide $(\mathrm{CdS})$ due to increased $\mathrm{OM}$ loading with consequent sulphide production/Cd precipitation, and the other being $\mathrm{Cd}$ contamination derived directly from municipal outfall particulates. The first explanation, while having immediate appeal, seems implausible especially if the Cd sequestration via precipitation is slow as proposed by Sundby et al. (2004); the Cd-enriched zone has been deposited predominantly during the past $\sim 20$ years. Furthermore, there is no evidence of an increase in any of the other redox tracers in the surface layer - in fact, they all decrease slightly, which leaves the $\mathrm{Cd}$ behaviour distinctly odd. The sediment cores at the other GVRD stations and the St. Lawrence box cores collected by Sundby et al., (2004) all support the point of view that the Cd build-up at this station relates to something other than redox chemistry.

The second explanation is that $\mathrm{Cd}$ enrichment at this core site reflects recent contamination from sewage particles themselves and this mechanism is supported by the Ag profile which also shows SML enrichment (Fig. 2; Table 3). Effluents from municipal outfalls contain a wide variety of anthropogenic contaminants, but previous attempts to use metals other than Ag to identify outfall particulates have not been successful in the Strait of Georgia (e.g., see Dunn, 1998) leading to the conclusion that heavy metals contamination from outfalls is minor. Here we will examine the $\mathrm{Cd}-\mathrm{Zn}$ metal pair to evaluate whether municipal outfall particulates provide a

541 plausible explanation for the observations at GVRD-3. For this core, the average concentrations

542 in the SML for Cd and $\mathrm{Zn}$ are $0.34 \mu \mathrm{g} \mathrm{g}^{-1}$ and $99 \mu \mathrm{g} \mathrm{g}^{-1}$ respectively, yielding a $\mathrm{Zn} / \mathrm{Cd}$ ratio of

543 about 291 (Fig. 5). These concentrations may be compared with background values, prior to 544 installation of the deep outfall in 1988 , of $0.17 \mu \mathrm{g} \mathrm{g}^{-1}$ and $112 \mu \mathrm{g} \mathrm{g}^{-1}$ respectively $(\mathrm{Zn} / \mathrm{Cd} \sim 660)$, observed between $20-40 \mathrm{~cm}$ in the core where concentrations appear almost invariant with 
546 depth (e.g., Fig. 4 Cd profile (Zn not shown) and Fig. 5). Based on measurements made at Iona

547 and Lions Gate in $1997(\mathrm{n}=4$ at each) and at Lions Gate in $2006(\mathrm{n}=12)$, the $\mathrm{Zn} / \mathrm{Cd}$ ratio in

548 Greater Vancouver effluent is $~ 105-128$. Solving the simultaneous equations implied by these

549 observations, we find that the SML composition can be produced by mixing background

550 particulates with outfall particulates in the ratio of 65:35 with the outfall particulates containing

$5510.65 \mu \mathrm{g} \mathrm{g}^{-1} \mathrm{Cd}$ and $78 \mu \mathrm{g} \mathrm{g}^{-1} \mathrm{Zn}$. The implication of these estimates is that the sedimentation rate

552 at this site would have to have increased by $\sim 35 \%$ in response to the installation of the deep

553 outfall, which agrees with model results showing a 25\% sedimentation rate increase near this site

554 (Hodgins and Hodgins, 2000) following installation of the outfall pipes. The ${ }^{210} \mathrm{~Pb}$ profile (Fig.

5553 ), however, sheds little light on any recent sedimentation increase, which would be confounded

556 by mixing processes in the SML.

557 With regard to OM forcing at this site, this core supports the highest organic carbon oxidation 558 rate $\left(12 \mathrm{mg} \mathrm{C} \mathrm{cm}^{-2} \mathrm{yr}^{-1}\right.$; Table 4), and the depression in $\delta^{15} \mathrm{~N}$ in the top $15 \mathrm{~cm}$ (2.5\%o compared to $5593.8 \%$ o deep in the core) implies that there has recently ( last 20 years) been a considerable 560 addition of OM carrying a low $\delta^{15} \mathrm{~N}$ signal (=2.5\%o), which points to primary-treated sewage 561 (Sweeney and Kaplan, 1980; Spies et al., 1989) or, possibly, nitrogen fertilizers used for 562 agriculture in the Fraser Valley (Wassenaar, 1995). The proximity to the GVRD outfall together 563 with the change from shore disposal to a deep outfall pipe (60-90 m) in 1988 at Iona provide 564 strong circumstantial evidence pointing to the Iona outfall source but, unfortunately, there are no 565 data for $\delta^{15} \mathrm{~N}$ in municipal particulates. If we accept $\mathrm{Cd}$ enrichment to derive from outfall 566 particulates at this site, then it is not surprising that $\mathrm{Cd}$ and $\delta^{15} \mathrm{~N}$ strongly correlate with one 567 another $\left(\delta^{15} \mathrm{~N}=4.98-7.10 \times \mathrm{Cd} ; \mathrm{r}^{2}=0.91, v=18 ; \mathrm{p}<0.001\right)$. Furthermore, the outfall 568 particulate assignment for $\mathrm{Cd}\left(0.65 \mu \mathrm{g} \mathrm{g}^{-1}\right)$ implies that outfall OM must have a $\delta^{15} \mathrm{~N}$ of $\sim 0.4 \pm$ $5691.0 \%$ with, again, the implication that $\sim 35 \%$ of the OM arriving at the surface of GVRD-3 570 derives from the deep outfall. Exceptional inventories and fluxes of U (Tables 3 \& 6) add weight 571 to the notion that this site has an active microbial community which is presently being fed in large 572 part by metabolizable outfall particulate organics. 
574

This core is difficult to interpret because the ${ }^{210} \mathrm{~Pb}$ profile provides no secure basis of dating (Fig. 3; Table 2), and the redox profiles are noisy near the sediment surface. The Ag profiles (and possibly $\delta^{15} \mathrm{~N}$ ) suggest that this site receives outfall OM (either from Iona Island or from Annacis Island (Fraser River), or agricultural OM via the Fraser River. Nevertheless, the metabolizable OC inventory is small over the depth of the core.

This core exhibits moderate redox activity on the suboxic/anoxic side based on the inventories (Table 3). There is no evidence of recent change in the core, but the organic composition (Table 5) suggests that this site receives an even mix of terrestrial and marine components. High sedimentation rates at this site would tend to reduce the time frame over which authigenic elements could accumulate so that we would expect at best muted signals in this core, even if fluxes of redox elements are comparable to other sites.

\section{6. $G V R D-5$}

GVRD-5, which is located well out in the main basin of the Strait, was collected at the deepest site $(388 \mathrm{~m})$ in this study. It exhibits a relatively high sedimentation rate and a SML with relatively low mixing (Table 2). Oxidizable OC at this site is not especially high, and the source of the carbon is weighted toward the marine ( $66 \%$ ). The lack of any strong Ag signal (Fig. 2) or $\delta^{15} \mathrm{~N}$ trends in the core, suggest that municipal outfall particulates do not directly play a strong role at the site. Furthermore, the higher sedimentation rate, deeper SML and higher Mn enrichment suggest that conditions to form a detectable Ag signal like that observed at GVRD-1 are not present. The relatively high inventory of excess ${ }^{210} \mathrm{~Pb}$ ( 2 to 3 times most other sites) indicates sediment focussing at this site.

GVRD-5 appears to be fed by a modest flux of reworked marine OM, based on the high $\delta^{15} \mathrm{~N}$ values, which supports an exceptionally clear redox zonation from Mn enrichment to AVS production in the top $5 \mathrm{~cm}$ of the core. Mo may reflect enrichment associated with precipitated manganese oxides near the sediment surface and $\Sigma$ S/AVS below about $10 \mathrm{~cm}$. This would explain the dichotomy between Mo enrichments and a lack of $\mathrm{Cd}, \mathrm{Re}$ and $\mathrm{U}$ enrichments in this core. The latter three elements experience a $10 \mathrm{~cm}$ SML, which is at least occasionally oxic as 
601

602

603

604

605

606

607

608

609

610

611

612

613

614

615

616

617

618

619

620

621

622

623

624

625

626

627

628

shown by Mn enrichment, through which they must diffuse to precipitate in the sulphide zone as marked by AVS. On the other hand, Mo is sequestered by Mn oxides such that when the Mn is reduced near the bottom of the SML and remobilized, the Mo can then efficiently transfer to pyrite phases, which increase below about $10 \mathrm{~cm}$.

\subsection{GVRD-6}

This core exhibits the highest sedimentation rate (except, probably, for core GVRD-4), an exceptionally large ${ }^{210} \mathrm{~Pb}$ inventory (Table 2 ) and a large $\mathrm{OC}$ burial rate, implying extraordinary focussing of inorganic and OM at this location. The deep SML $(12 \mathrm{~cm})$ together with high mixing coefficient $\left(20 \mathrm{~cm}^{2} \mathrm{yr}^{-1}\right)$ (Table 2$)$ imply active foraging, which is supported by the large oxidation rate estimated for this site (Table 4). In keeping with the enriched supply of OM through focussing, this site has unusually high infaunal biomass considering the depth $(187 \mathrm{~m})$ of this station (Burd et al., submitted). GVRD-6 likely receives resuspended sediments both from the Fraser delta slope and from inflowing water which is vigorously mixed to resuspend sediments in the Gulf Island passages (see Johannessen et al., 2005b; Johannessen et al., 2006). As was the case for GVRD-5, the OM in this core is strongly marine ( 70\%) and little influenced by municipal particulates based on $\delta^{15} \mathrm{~N}$ and $\mathrm{Ag}$ (Table 5; Fig. 2).

The GVRD-6 core provides an excellent contrast with the GVRD-1 core given the large differences between the two sites in sediment accumulation rate (2.7 vs $\left.0.078 \mathrm{~g} \mathrm{~cm}^{-2} \mathrm{yr}^{-1}\right)$ and OC oxidation rate ( 8.6 versus $0.7 \mathrm{mg} \mathrm{C} \mathrm{cm}^{-2} \mathrm{yr}^{-1}$ ). Only a small amount of excess $\mathrm{Mn}$ is held near the top of both cores (Table 3), implying that despite the relatively high OC oxidation at GVRD-6, there remains a surface oxic zone probably supported by the rapid addition of new inorganic material. In this case, Mn proves an unreliable indicator of OC oxidation rate. The other redox markers are almost constant down the core GVRD-6, and at considerably lower concentration than observed at GVRD-1. Apparently, the high sedimentation rate tends to overrule high concentration build-up for this core, but the actual fluxes of sequestered elements are large for $\Sigma \mathrm{S}, \mathrm{Cd}, \mathrm{U}$ and $\mathrm{Re}$, as one might expect considering the active $\mathrm{OC}$ oxidation rate. The rapid sedimentation rate together with OC metabolism provides an active conveyor belt to burial at GVRD-6. The exception is Mo, which exhibits the lowest sequestration rate of all cores. 


\subsection{GVRD-7}

GVRD-7 is also from deep water (233 m) but is located close to the Fraser Delta (Fig. 1). This core has a moderate sedimentation rate but exhibits no evidence of the focussing seen at GVRD-6 (Table 2). As a consequence, this core contains only a small OC inventory, little metabolizable OC and a very weakly mixed SML (Tables $2 \& 4$ ) which agrees with the low invertebrate biomass observed at this site (Burd et al., submitted). The OM reaching this site is $60 \%$ marine.

The prominent feature that sets this core apart from the others is the discontinuity between approximately 10 and $20 \mathrm{~cm}$, which is evident in the excess ${ }^{210} \mathrm{~Pb}$ profile (Fig. 2), low Mn values (with a high value at the bottom of the zone), and below the ${ }^{210} \mathrm{~Pb}$ minimum are found high $\Sigma \mathrm{S}$, Mo, Re and U concentrations (Fig. 4). The porosities (not shown) also are anomalously low in this depth range. The most plausible explanation for this feature is a rapid sedimentation event (sediment slump), similar to that observed by Macdonald et al. (1991), which has buried an old surface and contributed a rapid pulse of new sediment containing OM. The higher Mn concentration at the bottom of the slump is easily explained as a buried, Mn-enriched surface (converted to carbonate) and, above the slump, Mn enrichments are associated with the modern surface (top $5 \mathrm{~cm}$ ). Within and below the slump, there are clear enrichments of Mo, Re and $\mathrm{U}$ suggesting that sediments within the slumped layer remained suboxic as sedimentation $(0.3 \mathrm{~cm}$ $\mathrm{yr}^{-1}$ ) slowly covered it. Based on the sedimentation rate, the slump occurred 20-30 years ago which suggests that the observed enrichments have occurred within that time frame. The $\mathrm{Cd}$ profile is almost vertical within this region, suggesting that conditions for its enrichment did not occur. However, it is possible that the coarse turbidite in the slump had lower background $\mathrm{Cd}$ values and that enrichment, like those observed for Re, Mo, and U has simply 'filled in' this region of the core. Unfortunately, we have no AVS data for this core from which to evaluate recent $S$ precipitation.

GVRD-7 appears to be at the low end of the OM flux spectrum as reflected by most of the redox markers, which show little or no enrichment deep in the core, a recent surface layer enriched in Mn oxides, and a low biomass (Burd et al., submitted). The OM contained within the slump has interrupted the redox steady state with the consequence that elements have been 
precipitated in the suboxic and/or sulphidic layer defining the slump. Nevertheless, the inventories and average fluxes in this core are similar to those for GVRD-2, which has a comparable sedimentation rate, suggesting that the slump has not had any significant effect on the overall redox processes although it has clearly reshaped the deposition within the core. $\Sigma \mathrm{S}$ is an exception; the enrichments deep in the core, which are second only to GVRD-1 (Fig. 4), suggest that the slump may have resulted in a much greater role for sulphate reduction.

\section{Comparison of the GVRD core sites}

The settings of these cores vary widely, from GVRD-1, which receives predominantly marine reworked OM accumulating very slowly, to GVRD-5 and -7, which receive both marine and terrigenous material with intermediate sedimentation rates, to GVRD-6, which has exceptional amounts of sediment and organic carbon focussed into it, to GVRD-3 and -2, which are receiving significant inputs of municipal outfall particulate $\mathrm{OM}$. The wide range in natural settings renders it difficult to tease out the effects of modest amounts of added labile OM at any given site. One other study, Sundby et al. (2004), has examined redox elemental distributions in coastal and estuarine sediments in a way that enables direct comparison with the flux estimates made for the Strait of Georgia study. We note that for low sedimentation rates $\left(0.03\right.$ to $\left.0.64 \mathrm{~g} \mathrm{~cm}^{-2} \mathrm{y}^{-1}\right)$ and low organic metabolic rates $\left(0.2-2.2 \mathrm{mg} \mathrm{C} \mathrm{cm}^{-2} \mathrm{y}^{-1}\right)$, both studies produce surprisingly similar results in the rates of redox element sequestration, with the Strait of Georgia results generally exhibiting higher rates for $\mathrm{Mo}, \mathrm{Cd}, \mathrm{Re}$ and $\mathrm{U}$, although ranges do overlap. In particular, GVRD-2, one of the sites likely to be receiving OM input from outfalls, does not stand out as abnormal in the average fluxes of redox markers with the possible exception of the relatively high rate of $U$ sequestration.

The two stations with high sedimentation rates (GVRD-3 and -6) add a new dimension. Here, it is clear that all of the fluxes, including OC metabolism, sulphate reduction and elemental sequestration are much greater than those for the low-range sedimentation sites with the noteworthy exception of Mo. In examining the total data set for the Strait of Georgia (omitting GVRD-4 for which we have no flux data) and the Gulf of St. Lawrence, we find strong correlations between $\mathrm{Cd}, \mathrm{Re}, \mathrm{U}$ fluxes and sedimentation rate $\left(\mathrm{r}^{2}>0.81, \mathrm{n}=10, \mathrm{p}<0.005\right)$. Including only the GVRD data set, and adding OC metabolism, we find only U correlates 
significantly with OC $\left(\mathrm{r}^{2}=0.91, \mathrm{n}=6, \mathrm{p}<0.005\right)$. Molybdenum is distinct, and does not correlate significantly with any other parameter largely because it accumulates strongly at GVRD-5 and does not accumulate at GVRD-6, strongly opposing the other redox elements.

Sundby et al. (2004) concluded that slow kinetic reactions must be at play to explain Cd, Re, U and Mo profiles exhibiting increases with depth in cores, and our observations for the slow sedimentation sites fall into the same pattern. The significant correlation between sedimentation rate and $\mathrm{Cd}, \mathrm{Re}$ and $\mathrm{U}$ for our data set, however, suggests that there must also be a component of sequestration that rapidly places these elements into the particulate phase; that is, there is no reason to see why rate of diffusion would be faster for sediments that are accumulating faster unless at least part of the sequestration takes place rapidly toward the sediment surface. Further evidence of rapid sequestration (decadal scale) can be seen in GVRD-7 where the response to a turbidite layer has been to produce noteworthy peaks in Mo, $\mathrm{U}$ and Re within $\sim 30$ years.

\section{Conclusions}

The primary intention in this paper was to evaluate the potential for redox tracers to indicate the effect of added OM loadings from municipal outfalls to Strait of Georgia sediments, and also to produce a background set of sediment core data against which future change could be evaluated. The variety and range of redox conditions evident in the GVRD core collection makes this task difficult. Clearly, the natural setting of the Strait of Georgia provides a range of sites, some of which will have higher OC flux to sediment surface (e.g., GVRD-6) than exhibited at GVRD-3, the impacted site. The impacted site at GVRD-3, however, has the highest OC oxidation rate observed in our cores, and this likely reflects enhanced loading of labile OC from the municipal outfall $0.5 \mathrm{~km}$ away. Clearly, the natural variability observed in the cores collected for this study suggests that added labile OC loadings will have different effects depending on the site. The redox markers at GVRD-3 do not show significant changes that can be assigned to this extra organic carbon, and the only clear signal in redox elements seen at GVRD-3 appears in the $\mathrm{Cd}$ profile. Based on other data $\left(\delta^{15} \mathrm{~N}, \mathrm{Zn} / \mathrm{Cd}\right.$ ratio) we find this signal likely to derive from $\mathrm{Cd}$ enriched outfall particulates - that is, contamination - and not from organic forcing.

Our findings here suggest that sediment profiles for a suite of redox markers $(\mathrm{Mn}, \mathrm{Cd}, \mathrm{Re}, \mathrm{Mo}$, $\mathrm{U}, \mathrm{AVS}, \Sigma \mathrm{S}$ ) can be used to infer redox zonation in sediments and, given inventories and 
sedimentation rate data, these can be used to assess the average sequestration rates over the lifetime of the sediment column captured by the corer. The contrast between two stations distant from outfalls, GVRD-1 (slow sedimentation rate, low OC oxidation rate) and GVRD-6 (high sedimentation rate, high OC oxidation rate), is instructive. Concentration profiles of redox elements by themselves may be misleading in that these are strongly affected by sedimentation rate and sediment porosity, but these problems can be overcome by dating the cores and evaluating fluxes in common units. The build-up in various redox element concentrations (Mo, $\mathrm{Cd}, \mathrm{U}, \mathrm{Re}, \Sigma \mathrm{S})$ at GVRD-1 suggests, at first glance, that this core has very active sequestration compared to GVRD-6 which exhibits much lower concentrations. Furthermore, the OC contents in the sediments of the respective sites nicely agree with this image, with much higher OC concentrations observed at GVRD-1 (3-4\% compared to $1.1-1.4 \%)$. However, when the sedimentation rates are taken into account, it becomes clear that high porosity and slow sedimentation rate at GVRD-1 develop an excellent signal in the redox marker concentrations, but the site actually supports low OC oxidation rates, because most of the OC is recalcitrant, and low redox element sequestration rates. Viewed in this context, the two sites, GVRD-2 and -3, likely receive municipal outfall particulates directly as indicated by $\mathrm{Ag}$. Of these two sites, GVRD-3 appears to have enhanced OC oxidation rates and both sites exhibit large inventories of $\mathrm{U}$, which may be a response to the abundance of reactive $\mathrm{OM}$ and attendant microbial activity (Lovely et al., 1991; Sundby et al., 2004). The reversed profiles for Re, U and Mo at GVRD-2, which increase toward the sediment surface, might be produced by enhanced OM loadings following 1966, when the Lions Gate outfall was constructed, but for neither GVRD-2 nor GVRD-3 is there a compelling image of disturbance written in the redox elements. care is also needed in selecting the domain over which to use Ag as a sewage particle tracer, as proposed in a number of studies. The general contamination of the Strait of Georgia by anthropogenic Ag appears to support higher Ag fluxes to the sediments at this distal site. The Ag concentration signal is likely enhanced at this site but, as discussed for other redox tracers, the inventory of contaminant Ag remains low, which distinguishes this site from ones close to Ag sources. 


\section{ACCEPTED MANUSCRIPT}

We appreciate the assistance of the officers and crew of the CCGS Vector during the sediment coring operations. Flett Research Ltd., in Winnipeg, Canada measured radioisotopes in the sediment cores, and figures were prepared by Patricia Kimber. Funding for this work was provided by a collaborative agreement with Metro Vancouver (formerly Greater Vancouver Regional District) as part of the Strait of Georgia Ambient Monitoring Program, by Environment Canada, through the Georgia Basin Action Plan, and by Fisheries and Oceans Canada. We gratefully acknowledge the perspectives given by Dr. J. Crusius and an anonymous reviewer, which helped us to improve the paper.

\section{References}

Allen, H.E., Fung, G. and Deng, B., 1993. Analysis of Acid-Volatile Sulfide (AVS) and Simultaneously Extracted Metals (SEM) for the estimation of potential toxicity in aquatic sediments. Environmental Toxicology and Chemistry, 12, 1441-1453.

Bennett, E.R. and Metcalfe, C.D., 2000. Distribution of degradation products of alylphenol ethoxylates near sewage treatment plants in the lower Great Lakes, North America. Environmental Toxicology and Chemistry, 19, 784-792.

Bishop, J.K.B., 1989. Regional extremes in particulate matter composition and flux: effects on the chemistry of the ocean interior. In: Berger, W.H., Smetacek, V.S. and Wefer, G., (Eds.). Productivity of the Ocean: Present and Past. J. Wiley \& Sons Limited, Dahlem, pp. 117-137.

Borchers, S.L., Schnetger, B., Böning, P. and Brumsack , H.-J., 2005. Geochemical signatures of the Namibian diatom belt: Perennial upwelling and intermittent anoxia. Geochemistry Geophysics Geosystems, 6, doi:10.1029/2004GC000886.

Bornhold, B.D., 1978. Carbon/nitrogen (C/N) ratios in surficial marine sediments of British Columbia. Geological Survey of Canada,

Calvert, S.E., Pedersen, T.F. and Karlin, R.E., 2001. Geochemical and isotopic evidence for postglacial palaeoceanographic changes in Saanich Inlet, British Columbia. Marine Geology, 174, 287-305.

Calvert, S.E., Pedersen, T.F., Naidu, P.D. and von Stackelberg, U., 1995. On the organic carbon maximum on the continental slope of the eastern Arabian Sea. Journal of Marine Research, 53, 269-196.

Cloern, J.E., 2001. Our evolving conceptual model of the coastal eutrophication problem. Marine Ecology Progress Series, 210, 223-253.

Cochran, J.K., Carey, A.E., Scholkovitz, E.R. and Surprenant, L.D., 1986. The geochemistry of uranium and thorium in coastal marine sediments and sediment pore waters. Geochimica et Cosmochimica Acta, 50, 663-680.

Colodner, D., Sachs, J., Ravizza, G., Turekian, K., Edmond, J. and Boyle, E., 1993. The geochemical cycle of rhenium: a reconnaissance. Earth and Planetary Science Letters, $117,205-221$. 
Crusius, J., Calvert, S., Pedersen, T. and Sage, D., 1996. Rhenium and molybdenum enrichments in sediments as indicators of oxic, suboxic and sulfidic conditions of deposition. Earth and Planetary Science Letters, 145, 65-78.

Crusius, J. and Thomson, J., 2003. Mobility of authigenic rhenium, silver, and selenium during postdepositional oxidation in marine sediments. Geochimica et Cosmochimica Acta, 67, 265-273.

Crusius, J. and Thomson, J., 2000. Comparative behavior of aughigenic Re, U, and Mo during reoxidation and subsequent long-term burial in marine sediments. Geochimica et Cosmochimica Acta, 64, 2233-2242.

de Baar, H.J.W., Saager, P.M., Nolting, R.F. and van der Meer, J., 1994. Cadmium versus phosphate in the world ocean. Marine Chemistry, 46, 261-281.

Diaz, J.R. and Rosenberg, R., 1995. Marine benthic hypoxia: a review on its ecological effects and the behaviorial responses of benthic macrofauna. Oceanography Marine Biology, 33, 245-303.

Drysdale, K. and Pedersen, T.F., 1992. Geochemical behaviour of a buried marine mine tailings deposit, Howe Sound, British Columbia. In: Levings, C., Turner, R.B. and Ricketts, B. (Eds.). Howe Sound Environmental Science Workshop. Fisheries and Oceans Canada, 270pp pp.

Dunn, C.E., 1998. Geochemistry of seafloor sediments from the Strait of Georgia, British Columbia. In: Claugue, J.J., Luternauer, J.L. and Mosher, D.C., (Eds.). Geology and Natural Hazards of the Fraser River Delta, British Columbia. Geological Survey of Canada, Ottawa, pp. 257-270.

Erickson, B.E. and Helz, G.R., 2000. Molybdenum (VI) speciation in sulfidic waters. Stability and lability of thiomolybdates. Geochimica et Cosmochimica Acta, 64, 1149-1158.

Flegal, A.R. and Ranville, M.A., 2005. Silver in the North Pacific Ocean. Geochemistry, Geophysics, Geosystems, 6, 13pp.

Flegal, A.R., Sañudo-Wilhelmy, S.A. and Scelfo, G.M., 1995. Silver in the eastern Atlantic Ocean. Marine Chemistry, 49, 315-320.

Gearing, P.J., Gearing, J.N., Maughan, J.T. and Oviatt, C.A., 1991. Isotopic distribution of carbon from sewage sludge and eutrophication in the sediments and food web of estuarine ecosystems. Environmental Science and Technology, 25, 295-301.

GESAMP. 1990. The state of the Marine Environment. UNEP Regional Sea Reports and Studies. No. 115. UNEP Blackwell Scentific Publications, Oxford, UK.

Gilbert, D., Sundby, B., Gobeil, C., Mucci, A. and Tremblay, G.-H., 2005. A seventy-two-year record of diminishing oxygen in the St. Lawrence estuary: The northwest Atlantic connection. Limnology and Oceanography, 50, 1654-1666.

Gobeil, C., 1999. Silver in sediments from the St. Lawrence River and estuary and the Saguenay Fjord. Environmental Science and Technology, 33, 2953-2957.

Gobeil, C., Macdonald, R.W. and Sundby, B., 1997. Diagenetic separation of cadmium and manganese in suboxic continental margin sediments. Geochimica et Cosmochimica Acta, 61, 4647-4654.

Gobeil, C., Silverberg, N., Sundby, B. and Cossa, D., 1987. Cadmium diagenesis in Laurentian Trough sediments. Geochimica et Cosmochimica Acta, 51, 589-596. 
Gobeil, C., Sundby, B., Macdonald, R.W. and Smith, J.N., 2001. Recent change in organic carbon flux to Arctic Ocean deep basins: Evidence from acid volatile sulfide, manganese and rhenium discord in sediments. Geophysical Research Letters, 28, 1743-1746.

Goñi, M.A., Yunker, M.B., Macdonald, R.W. and Eglinton, T.I., 2005. The supply and preservation of ancient and modern components of organic carbon in the Canadian Beaufort Shelf of the Arctic Ocean. Marine Chemistry, 93, 53-73.

Gordon, K., 1997. Sedimentary tracers of sewage inputs to the southern Strait of Georgia. Department of Earth and Ocean Sciences, University of British Columbia. MSc., 217 pp.

Hart, B.S., Hamilton, T.S. and Barrie, J.V., 1998. Sedimentation rates and patterns on a deepwater delta (Fraser delta, Canada): Integration of high-resolution seismic stratigraphy, core lithofacies and 137Cs fallout stratigraphy. Journal of Sedimentary Research, 68, 556568.

Hedges, J.I. and Keil, R.G., 1995. Sedimentary organic matter preservation: an assessment and speculative synthesis. Marine Chemistry, 49, 81-115.

Hodgins, D.O. and Hodgins, S.L.M., 2000. A Re-evaluation of Iona Effluent Solids Deposition Based on Sediment Grain Size Characteristics. In: (Eds.). Greater Vancouver Regional District. Development of a Receiving Environment Monitoring Approach to Liquid Waste Management. Progress Workshop 2 December 6, 2000. Greater Vancouver Regional District, Burnaby, BC, 1-1 -1-24 pp.

Johannessen, S.A., Macdonald, R.W. and Eek, M., 2005a. Historical trends in mercury sedimentation and mixing in the Strait of Georgia, Canada. Environmental Science and Technology, 39, 4361-4368.

Johannessen, S.C., Macdonald, R.W. and Paton, D.W., 2003. A sediment and organic carbon budget for the greater Strait of Georgia. Estuarine and Coastal Shelf Science, 56, 845-860.

Johannessen, S.C., Macdonald, R.W., Wright, C., Burd, B., Shaw, P. and van Roodselaar, A., 2008. Joined by geochemistry, divided by history: PCBs and PBDEs in Strait of Georgia sediments. Marine Environmental Research, in press,

Johannessen, S.A., Masson, D. and Macdonald, R.W., 2006. Spatial and temporal patterns of light attenuation in waters of the Strait of Georgia, Haro Strait and Juan de Fuca Strait: Implications for particle transport and cycling. Atmosphere-Ocean, 44, 17-27.

Johannessen, S.C., O'Brien, M.C., Denman, K.L. and Macdonald, R.W., 2005b. Seasonal and spatial variations in the source and transport of sinking particles in the Strait of Georgia, Canada. Marine Geology, 216, 59-77.

Klinkhammer, G.P. and Palmer, M.R., 1991. Uranium in the oceans: where it goes and why. Geochimica et Cosmochimica Acta, 55, 1799-1806.

Lavelle, J.W., Massoth, G.J. and Crecelius, E.A., 1985. Sedimentation rates in Puget Sound from ${ }^{210} \mathrm{~Pb}$ measurements. Pacific Marine Environmental Laboratory, Seattle.

Lehmann, M.F., Bernasconi, S.M., Barbieri, A. and McKenzie, J.A., 2002. Preservation of organic matter and alteration of its carbon and nitrogen isotope composition during simulated and in situ early diagenesis. Geochimica et Cosmochimica Acta, 66, 3573-3584.

Lovely, D.R., Phillips, E.J.P., Gorby, Y.A. and Landa, E.R., 1991. Microbial reduction of uranium. Nature, 350, 413-416.

Luoma, S.N., Ho, Y.B. and Bryan, G.W., 1995. Fate, bioavailability and toxicity of silver in estuarine environments. Marine Pollution Bulletin, 31, 44-54. 
Macdonald, R.W., Cretney, W.J., Crewe, N. and Paton, D.W., 1992. A history of octachlordibenzo-p-dioxin, 2,3,7,8-tetrachlorodibenzofuran, and 3,3',4,4'tetrachlorobiphenyl contamination in Howe Sound, British Columbia. Environmental Science and Technology, 26, 1544-1550.

Macdonald, R.W., Macdonald, D.M., O'Brien, M.O. and Gobeil, C., 1991. Accumulation of heavy metals $(\mathrm{Pb}, \mathrm{Zn}, \mathrm{Cu}, \mathrm{Cd})$, carbon and nitrogen in sediments from Strait of Georgia, B.C., Canada. Marine Chemistry, 34, 109-135.

Mackas, D.L. and Harrison, P.J., 1997. Nitrogenous nutrient sources and sinks in the Juan de Fuca Strait, Strait of Georgia, Puget Sound estuarine system: Assessing the potential for eutrophication. Estuarine and Coastal Shelf Science, 44, 1-21.

McKay, J.L., Pedersen, T.F. and Mucci, A., 2007. Sedimentary redox conditions in continental margin sediments (N.E. Pacific) - Influence on the accumulation of redox-sensitive trace metals. Chemical Geology, 238, 180-196.

Morford, J.L., Martin, W.R., Kalnejais, L.H., Francois, R., Bothner, M. and Karle, I.-M., 2007. Insight on geochemical cycling of $\mathrm{U}, \mathrm{Re}$ and Mo from seasonal sampling in Boston Harbour, Massachusetts, USA. Geochimica et Cosmochimica Acta, 71, 895-917.

Morford, J.L., Russel, A.D. and Emerson, S., 2001. Trace metal evidence for changes in the redox environment associated with the transition from terrigenous clay to diatomaceous sediment, Saanich Inlet, B.C. Marine Geology, 174, 355-369.

Morse, J.W. and Rickard, D., 2004. Chemical dynamics of sedimentary acid volatile sulfide. Environmental Science and Technology, 132A-136A.

Pedersen, T.F., Waters, R.D. and Macdonald, R.W., 1989. On the natural enrichment of cadmium and molybdenum in the sediments of Ucluelet Inlet, British Columbia. The Science of the Total Environment, 79, 125-139.

Rosenthal, Y., Lam, P., Boyle, E.A. and Thomson, J., 1995. Authigenic cadmium enrichments in suboxic sediments: Precipitation and postdepositional mobility. Earth and Planetary Science Letters, 99-111.

Sañudo-Wilhelmy, S.A. and Flegal, A.R., 1992. Anthropogenic silver in the southern bight: a new tracer of sewage in coastal waters. Environmental Science and Technology, 26, 21472151.

Schiedek, D., Sundelin, B., Readman, J.W. and Macdonald, R.W., 2007. Interactions between climate change and contaminants. Marine Pollution Bulletin, 54, 1845-1856.

Schlitzer, R. (2006). Ocean Data View.

Shang, D.Y., Macdonald, R.W. and Ikonomou, M.G., 1999. The persistence of nonylphenol ethoxylate surfactants and their primary degradation products in sediments from near a municipal outfall in the Strait of Georgia, British Columbia, Canada. Environmental Science and Technology, 33, 1366-1372.

Spies, R.B., Kruger, H., Ireland, R. and Rice, D.W.J., 1989. Stable isotope ratios and contaminant concentrations in a sewage-distorted foodweb. Marine Ecology Progress Series, 54,

Sundby, B., 2006. Transient state diagenesis in continental margin muds. Marine Chemistry, 102, $2-12$.

Sundby, B., Gobeil, C., Silverberg, N. and Mucci, A., 1992. The phosphorus cycle in coastal marine sediments. Limnology and Oceanography, 37, 1129-1145. 
Sundby, B., Martinez, P. and Gobeil, C., 2004. Comparative geochemistry of cadmium, rhenium, uranium and molybdenum in continental margin sediments. Geochimica et Cosmochimica Acta, 58, 2485-2493.

Sweeney, R.E. and Kaplan, I.R., 1980. Tracing flocculent industrial and domestic sewage transport on San Pedro shelf, southern California, by nitrogen and sulphur isotope ratios. Marine Environmental Research, 3, 215-224.

Taylor, S.R., 1964. Abundance of elements in the continental crust: a new table. Geochimica et Cosmochimica Acta, 28, 1273-1285.

Thomson, J., Nixon, S., Croudace, I.W., Pedersen, T.F., Brown, L., Cook, G.T. and MacKenzie, A.B., 2001. Redox-sensitive element uptake in north-east Atlantic Ocean sediments (Benthic Boundary Layer Experiment sites). Earth and Planetary Science Letters, 184, 535-547.

Turner, R.E., Rabalais, N.N. and Justic, D., 2008. Gulf of Mexico hypoxia: Alternate states and a legacy. Environmental Science and Technology, 42, 2323-2327.

Van Dover, C.L., Grassle, J.F., Fry, B., Garritt, R.H. and Starezak, V., 1992. Stable isotope evidence for entry of sewage-derived organic material into a deep-sea food web. Nature, 360, 153-156.

Wassenaar, L.I., 1995. Evaluation of the origin and fate of nitrate in the Abbotsford Aquifer using the isotopes of $15 \mathrm{~N}$ and $18 \mathrm{O}$ in $\mathrm{NO}_{3}{ }^{-}$. Applied Geochemistry, 10, 391-405.

Wright, C.A., Johannessen, S.C., Macdonald, R.W., Burd, B.J., Hill, P.R., van Roodselaar, A. and Bertold, S., 2008. The Strait of Georgia Ambient Monitoring Program, Phase I 20022007: Sediment and Benthos. Department of Fisheries and Oceans, Sidney, BC.

Yunker, M.B. and Macdonald, R.W., 2003. Alkane and PAH depositional history, sources and fluxes in sediments from the Fraser River Basin and Strait of Georgia. Organic Geochemistry, 34, 1429-1454.

Yunker, M.B., Macdonald, R.W., Goyette, D., Paton, D.W., Sullivan, D., Boyd, J. and Fowler, B.R., 1999. Natural and anthropogenic inputs of hydrocarbons to the Strait of Georgia. Science of the Total Environment, 225, 181-209. 
943 Figure Captions

944 Fig. 1. A chart showing the study area and the locations of the seven box cores.

945 Fig. 2. A map of Ag concentration in surface sediments (contours constructed from data produced 946 by Gordon (1997)) together with locations of the GVRD box coring sites. Sediment profiles of $947 \mathrm{Ag}$ for the seven GVRD sites are shown in the panels. Data were contoured within Ocean Data 948 View (Schlitzer, 2006)using the VG gridding algorithm.

949 Fig. 3. Vertical profiles of $\ln \left(\right.$ excess $\left.{ }^{210} \mathrm{~Pb}\right)$ (closed circles) and percent organic carbon (open 950 circles) for the seven box cores.

951 Fig. 4. Vertical profiles for the redox indicators including Mn, Acid Volatile Sulfide (AVS), S, 952 Cd, Mo, U and Re. Note scale changes on some panels (Mn - GVRD-5; S - GVRD-1; Cd 953 GVRD-1; U - GVRD-1 and -6 and -7; Re - GVRD-1). AVS data for GVRD-7 are not available.

954 Fig. 5. Vertical profile of the Zn/Cd ratio at GVRD-3 showing the recent change in the upper 955 core attributed here to municipal particulates. 
Table 1. Sediment core collection locations, water depths and dates of collection

\begin{tabular}{cccrc}
\hline $\begin{array}{c}\text { Station } \\
\text { name }\end{array}$ & $\begin{array}{c}\text { Latitude } \\
\left({ }^{\circ} \mathbf{N}\right)\end{array}$ & $\begin{array}{c}\text { Longitude } \\
\left({ }^{\circ} \mathbf{W}\right)\end{array}$ & $\begin{array}{c}\text { Water } \\
\text { Depth } \\
(\mathbf{m})\end{array}$ & $\begin{array}{c}\text { Date of } \\
\text { Collection }\end{array}$ \\
\hline GVRD-1 & $49^{\circ} 35.515^{\circ}$ & $124^{\circ} 38.282^{\prime}$ & 169 & June 2003 \\
GVRD-2 & $49^{\circ} 19.902^{\prime}$, & $123^{\circ} 18.517^{\prime}$ & 76 & June 2003 \\
GVRD-3 & $49^{\circ} 12.467^{\prime}$, & $123^{\circ} 17.991^{\prime}$, & 83 & December 2002 \\
GVRD-4 & $49^{\circ} 07.778^{\prime}$ & $123^{\circ} 18.718^{\prime}$ & 84 & December 2002 \\
GVRD-5 & $49^{\circ} 09.877^{\prime}$, & $123^{\circ} 32.731^{\prime}$ & 388 & December 2002 \\
GVRD-6 & $48^{\circ} 56.192^{\prime}$ & $123^{\circ} 18.812^{\prime}$ & 187 & June 2003 \\
GVRD-7 & $49^{\circ} 03.340^{\prime}$ & $123^{\circ} 22.162^{\prime}$ & 233 & December 2003 \\
\hline
\end{tabular}


Table 2. Sedimentation rates and surface mixing in sediment cores modeled from ${ }^{210} \mathrm{~Pb}$ profiles (profiles shown in Figure 3 ).

\begin{tabular}{|c|c|c|c|c|c|c|c|}
\hline $\begin{array}{c}\text { Core } \\
\text { Designation }\end{array}$ & $\begin{array}{l}\text { Supported } \\
{ }^{210} \mathrm{~Pb} \\
\left(\mathrm{dpm} \mathrm{g}^{-1}\right)\end{array}$ & $\begin{array}{c}\text { Excess }{ }^{210} \mathrm{~Pb} \\
\text { Flux } \\
\left(\mathrm{dpm} \mathrm{cm} \mathrm{cm}^{-2} \mathrm{yr}^{-1}\right)\end{array}$ & 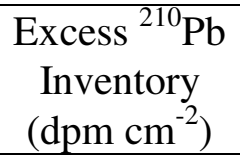 & $\begin{array}{c}\text { Sedimentation } \\
\text { velocity } \\
\left(\mathrm{cm} \mathrm{yr}^{-1}\right)\end{array}$ & $\begin{array}{c}\text { Sediment } \\
\text { accumulation rate } \\
\left(\mathrm{g} \mathrm{cm}^{-2} \mathrm{yr}^{-1}\right)\end{array}$ & $\begin{array}{l}\text { Surface mixed } \\
\text { layer depth } \\
(\mathrm{cm})\end{array}$ & $\begin{array}{l}\text { Mixing rate in } \\
\text { upper layer } \\
\left(\mathrm{cm}^{2} \mathrm{yr}^{-1}\right)\end{array}$ \\
\hline GVRD-1 & 0.67 & 1.4 & 45 & 0.25 & 0.078 & 7 & 3 \\
\hline GVRD-2 & 0.87 & 4.2 & 134 & 0.35 & 0.26 & 10 & 15 \\
\hline $\begin{array}{c}\text { GVRD-3 } \\
\text { (outfall) }\end{array}$ & 0.55 & 3.8 & 121 & 1.2 & 1.3 & 7 & 20 \\
\hline${ }^{\mathrm{a}}$ GVRD-4 & 1.76 & & unknown & unknown (> 3) & unknown (fast) & unknown & unknown \\
\hline GVRD-5 & 0.86 & 9.0 & 288 & 1.1 & 0.64 & 10 & 5 \\
\hline GVRD-6 & 0.58 & 65 & 2080 & 2.9 & 2.7 & 12 & 30 \\
\hline GVRD-7 & 0.68 & 2.5 & 80 & 0.30 & 0.32 & 12 & 0.5 \\
\hline
\end{tabular}

${ }^{\mathrm{a}}$ sedimentation and mixing rates for core GVRD-4 could not be determined accurately from the ${ }^{210} \mathrm{~Pb}$ data. 
Table 3. Inventories $\left(\mu \mathrm{g} \mathrm{cm}^{-2}\right)$ of redox markers in the GVRD sediment cores calculated from sediment profiles using background values $\left(\mu \mathrm{g} \mathrm{g}^{-1}\right)$ of: $\mathrm{Ag}-0.1 ; \mathrm{Mn}-400 ; \mathrm{AVS}-0 ; \Sigma \mathrm{S}-1500 ; \mathrm{Cd}-0.10 ; \mathrm{Mo}-1 ; \mathrm{U}-1.2 ; \operatorname{Re}-0.0023$.

\begin{tabular}{lrrrrrrrr}
\hline Core & \multicolumn{1}{c}{$\mathrm{Ag}$} & \multicolumn{1}{c}{$\mathrm{Mn}$} & \multicolumn{1}{c}{ AVS } & \multicolumn{1}{c}{$\Sigma \mathrm{S}$} & \multicolumn{1}{c}{$\mathrm{Cd}$} & \multicolumn{1}{c}{ Mo } & $\mathrm{U}$ & $\mathrm{Re}$ \\
\hline GVRD-1 & 0.67 & 43 & 350 & 110000 & 4.5 & 73.8 & 34.1 & 0.22 \\
GVRD-2 & 6.6 & 32 & 1810 & 25000 & 3.5 & 115.1 & 33.0 & 0.061 \\
GVRD-3 & 10.2 & 0 & 33390 & 50400 & $2.6^{\mathrm{a}}$ & 150.5 & 30.6 & 0.043 \\
GVRD-4 & 1.1 & $?$ & 10450 & 21900 & 2.1 & 139.3 & 11.4 & 0.017 \\
GVRD-5 & - & 409 & 25650 & 43000 & 1.3 & 154.5 & 10.3 & 0.023 \\
GVRD-6 & - & 82 & 16300 & 31400 & 5.4 & 1.8 & 13.4 & 0.032 \\
GVRD-7 & - & 312 & No data & 157000 & 2.3 & 84.5 & 16.7 & 0.071 \\
\hline
\end{tabular}

${ }^{\mathrm{a}}$ Corrected for contaminant $\mathrm{Cd}$ 
Table 4. Organic carbon fluxes, losses and burial in GVRD sediment cores.

\begin{tabular}{cccccccc}
$\begin{array}{c}\text { Core } \\
\text { designation }\end{array}$ & $\begin{array}{c}\text { \%OC in } \\
\text { incident } \\
\text { sedimentation }\end{array}$ & $\begin{array}{c}\text { \%OC } \\
\text { buried in } \\
\text { sediments }\end{array}$ & $\begin{array}{c}\text { OC burial } \\
\text { Depth } \\
(\mathrm{cm})\end{array}$ & $\begin{array}{c}\text { OC flux to } \\
\text { surface } \\
\left(\mathrm{mg} \mathrm{C} \mathrm{cm}^{-2} \mathrm{yr}^{-1}\right)\end{array}$ & $\begin{array}{c}\text { Oxidizable } \\
\text { OC Inventory } \\
\left(\mathrm{g} \mathrm{cm}^{-2}\right)\end{array}$ & $\begin{array}{c}\text { OC burial rate } \\
\left(\mathrm{mg} \mathrm{C} \mathrm{cm}^{-2} \mathrm{yr}^{-1}\right)\end{array}$ & $\begin{array}{c}\text { OC oxidation } \\
\mathrm{rate}^{-2} \\
\left(\mathrm{mg} \mathrm{cm}^{-2} \mathrm{yr}^{-1}\right)\end{array}$ \\
\hline GVRD-1 & 4.1 & 3.2 & 30 & 3.2 & 0.042 & 2.5 & 0.70 \\
GVRD-2 & 1.8 & 0.76 & 45 & 3.8 & 0.138 & 1.6 & 2.2 \\
GVRD-3 & 1.7 & 0.80 & 35 & 23 & 0.047 & 11 & 12 \\
aGVRD-4 & 1.0 & 0.91 & $20(20-35)$ & unknown & 0.0077 & unknown & unknown \\
GVRD-5 & 1.8 & 1.5 & 50 & 12 & 0.035 & 9.6 & 1.9 \\
GVRD-6 & 1.4 & 1.1 & 45 & 38 & 0.052 & 29 & 8.6 \\
GVRD-7 & 1.1 & 0.98 & 45 & 3.3 & 0.013 & 3.0 & 0.22 \\
\hline
\end{tabular}

${ }^{\mathrm{a}}$ Due to the difficulty in assigning sedimentation rate to this core, fluxes were not calculated. OC loss in sediments was estimated from

${ }^{210} \mathrm{~Pb}$-derived sedimentation rate and the $\mathrm{OC}$ vertical profile in each core by assuming that decrease in $\% \mathrm{OC}$ with depth is a first-order process and that oxidation ceases at the depth in the core below which \%OC does not change. 
Table 5. Average sediment core properties for organic matter composition

\begin{tabular}{ccccccc}
\hline $\begin{array}{c}\text { Core } \\
\text { designation }\end{array}$ & $\begin{array}{c}\text { Average } \\
\text { Porosity }(\varphi)\end{array}$ & $\begin{array}{c}\text { Number of } \\
\text { Samples }(\mathrm{n})\end{array}$ & Average C/N $\pm \mathrm{SE}$ & $\begin{array}{c}\text { Average } \delta^{13} \mathrm{C} \pm \\
\mathrm{SE}\end{array}$ & $\begin{array}{c}\text { Average } \delta^{15} \mathrm{~N} \pm \\
\mathrm{SE}\end{array}$ & ${ }^{\mathrm{a}} \mathrm{F}_{\text {marine }}$ \\
\hline GVRD-1 & 0.91 & 22 & $8.08 \pm 0.06$ & $-20.95 \pm 0.10$ & $6.46 \pm 0.05$ & 0.75 \\
GVRD-2 & 0.76 & 20 & $10.84 \pm 0.18$ & $-23.96 \pm 0.05$ & $4.48 \pm 0.04$ & 0.53 \\
GVRD-3 & 0.71 & 20 & $9.79 \pm 0.14$ & $-24.47 \pm 0.03$ & $3.12 \pm 0.14$ & 0.60 \\
GVRD-3 (top) & & 10 & $9.71 \pm 0.26$ & $-24.47 \pm 0.04$ & $2.56 \pm 0.09$ & 0.60 \\
GVRD-3 (bottom) & & 10 & $9.78 \pm 0.12$ & $-24.51 \pm 0.05$ & $3.79 \pm 0.06$ & 0.60 \\
${ }^{\mathrm{a}}$ GVRD-4 & 0.60 & 18 & $11.10 \pm 0.11$ & $-24.69 \pm 0.03$ & $3.44 \pm 0.03$ & 0.52 \\
GVRD-5 & 0.79 & 21 & $9.02 \pm 0.15$ & $-22.77 \pm 0.04$ & $5.61 \pm 0.05$ & 0.66 \\
GVRD-6 & 0.72 & 20 & $8.33 \pm 0.04$ & $-22.18 \pm 0.06$ & $5.64 \pm 0.03$ & 0.72 \\
GVRD-7 & 0.62 & 20 & $9.57 \pm 0.23$ & $-23.10 \pm 0.06$ & $5.22 \pm 0.05$ & 0.62 \\
\hline
\end{tabular}

${ }^{a}$ Estimated using average $\mathrm{C} / \mathrm{N}$ ratio and $\delta^{13} \mathrm{C}$ composition together with end-member assignments of $\mathrm{C} / \mathrm{N}$ marine $=6.2, \mathrm{C} / \mathrm{N}$ terrestrial $=90, \delta^{13} \mathrm{C}$ marine $=-19.7 \%$ o, $\delta^{13} \mathrm{C}$ terrestrial $=-25.0 \%$ (Macdonald et al., 1991$)$. 
Table 6. Rates of sequestering redox elements $\left(\mu \mathrm{g} \mathrm{cm}^{-2} \mathrm{yr}^{-1} 1\right)$ under reducing conditions.

\begin{tabular}{ccccccc}
\hline Core & AVS & $\Sigma \mathrm{S}$ & $\mathrm{Cd}$ & Mo & $\mathrm{U}$ & $\mathrm{Re}$ \\
\hline GVRD-1 & 1.88 & 584 & 0.024 & 0.39 & 0.181 & 0.00129 \\
GVRD-2 & 15.9 & 222 & 0.031 & 1.01 & 0.290 & 0.00059 \\
GVRD-3 & 938 & 1418 & 0.074 & 4.23 & 0.861 & 0.00136 \\
GVRD-4 & na & na & na & na & na & na \\
GVRD-5 & 568 & 951 & 0.028 & 3.42 & 0.228 & 0.00055 \\
GVRD-6 & 1161 & 2236 & 0.384 & 0.13 & 0.956 & 0.00249 \\
GVRD-7 & & 1066 & 0.017 & 0.62 & 0.123 & 0.00058 \\
\hline
\end{tabular}


Figure 2

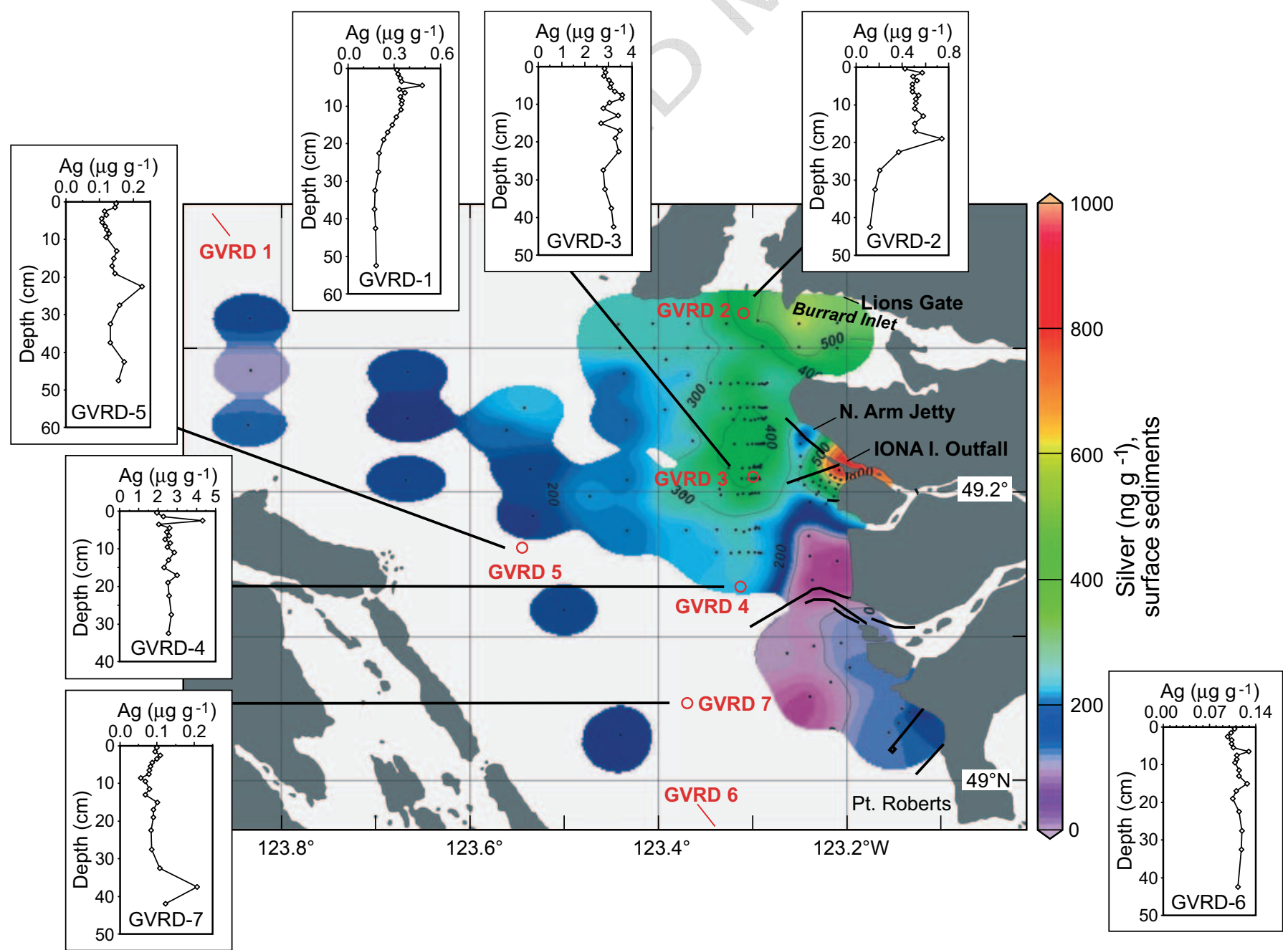


Figure 3

In (Excess $\left.{ }^{210} \mathrm{~Pb}\right)$

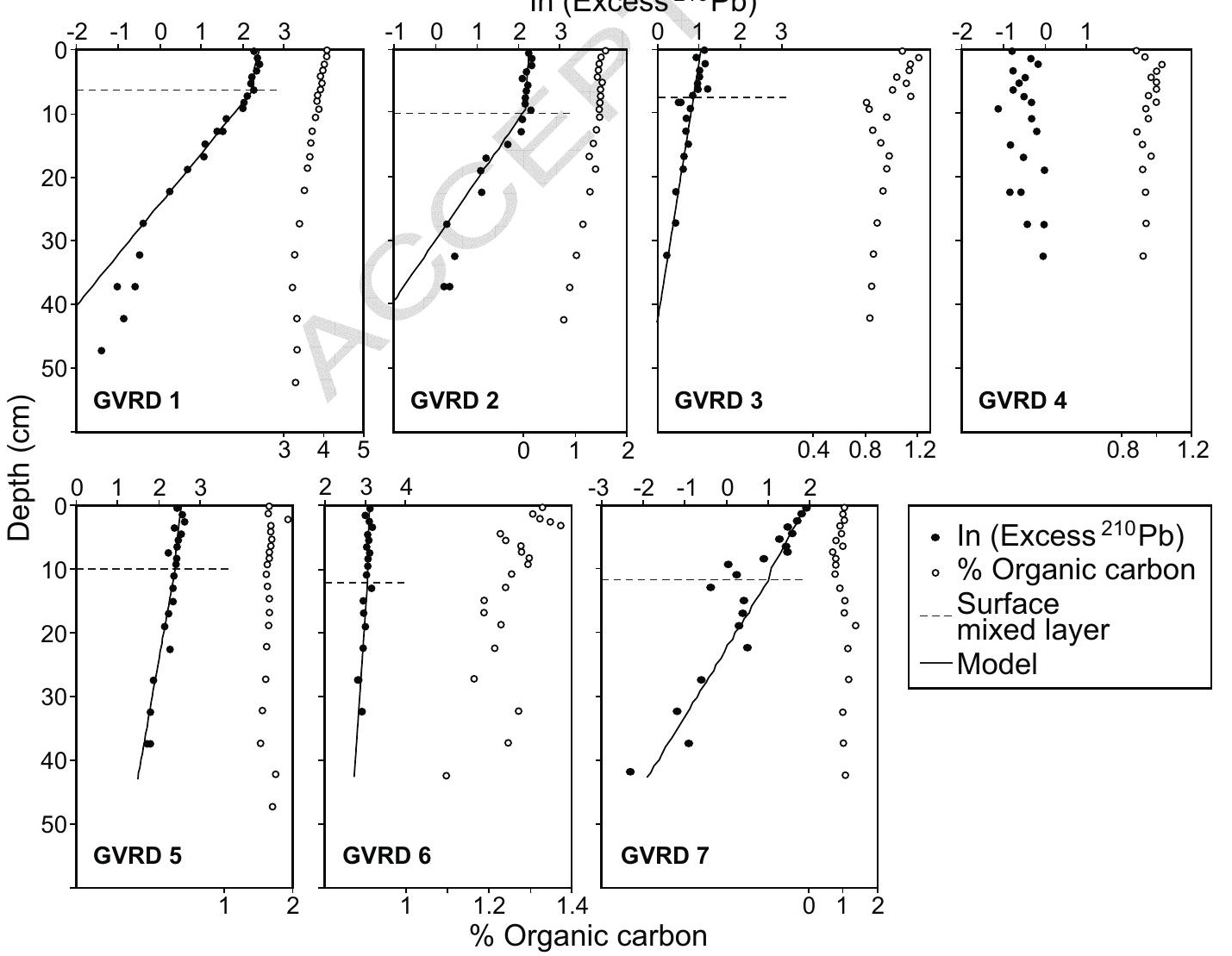


$\operatorname{Mn}\left(\mu g^{-1}\right) \quad$ AVS $\left(\mu g g^{-1}\right) \quad S\left(\mu g^{-1}\right) \quad C d\left(\mu g g^{-1}\right) \quad M o\left(\mu g g^{-1}\right) \cup\left(\mu g g^{-1}\right) \operatorname{Re}\left(n g g^{-1}\right)$
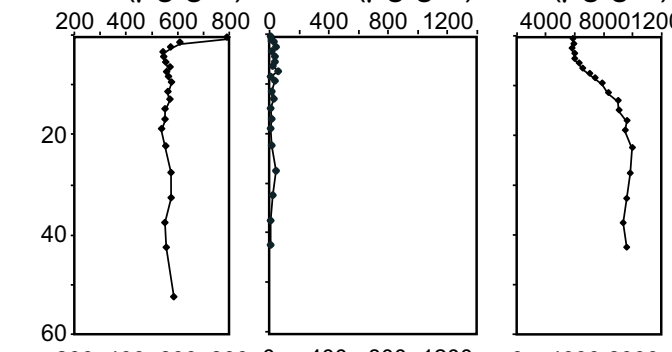

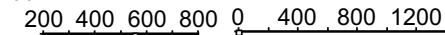

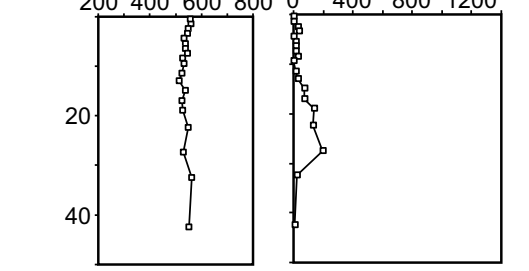

commen
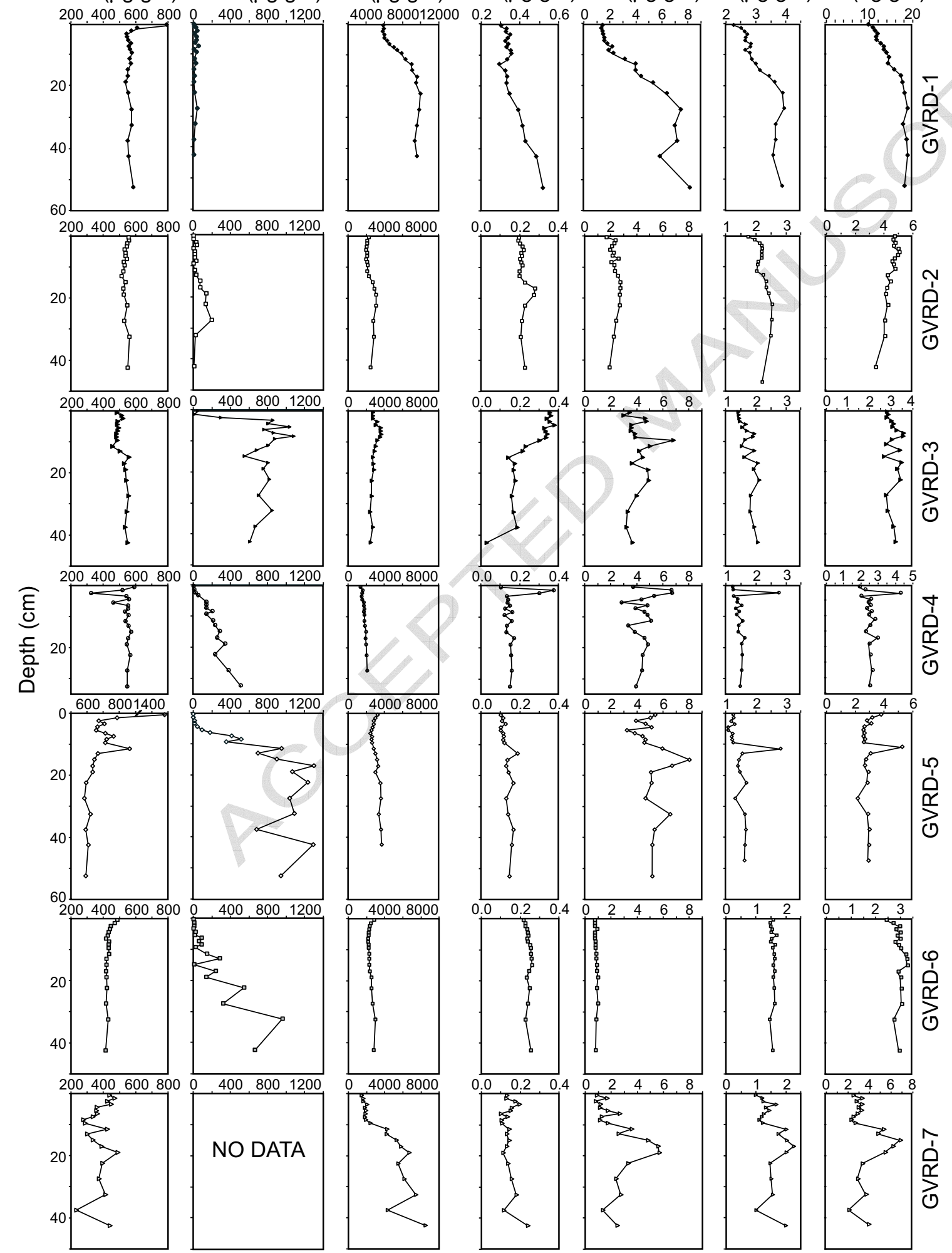

toosecose
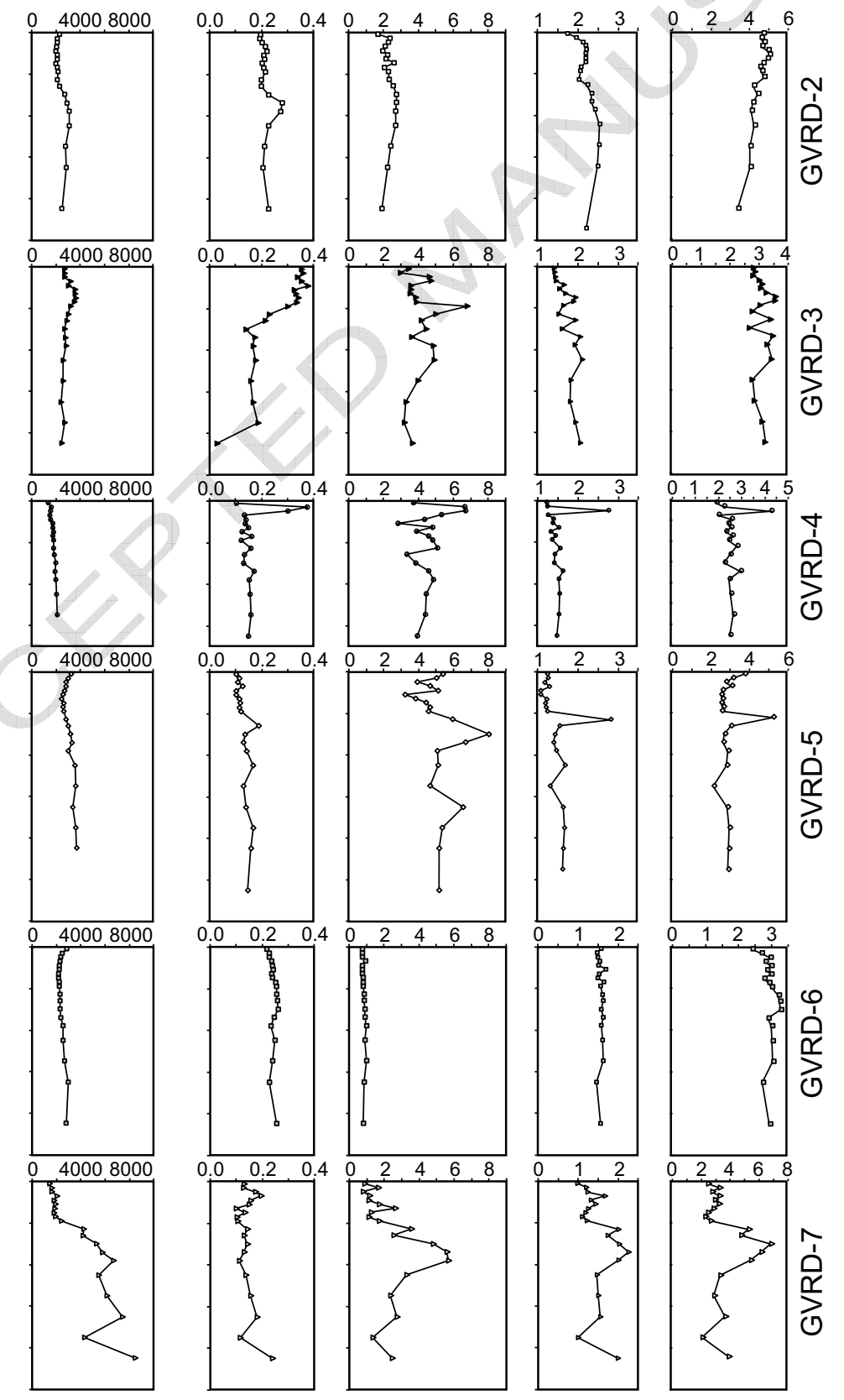


\section{ACCEPTED MANUSCRIPT}

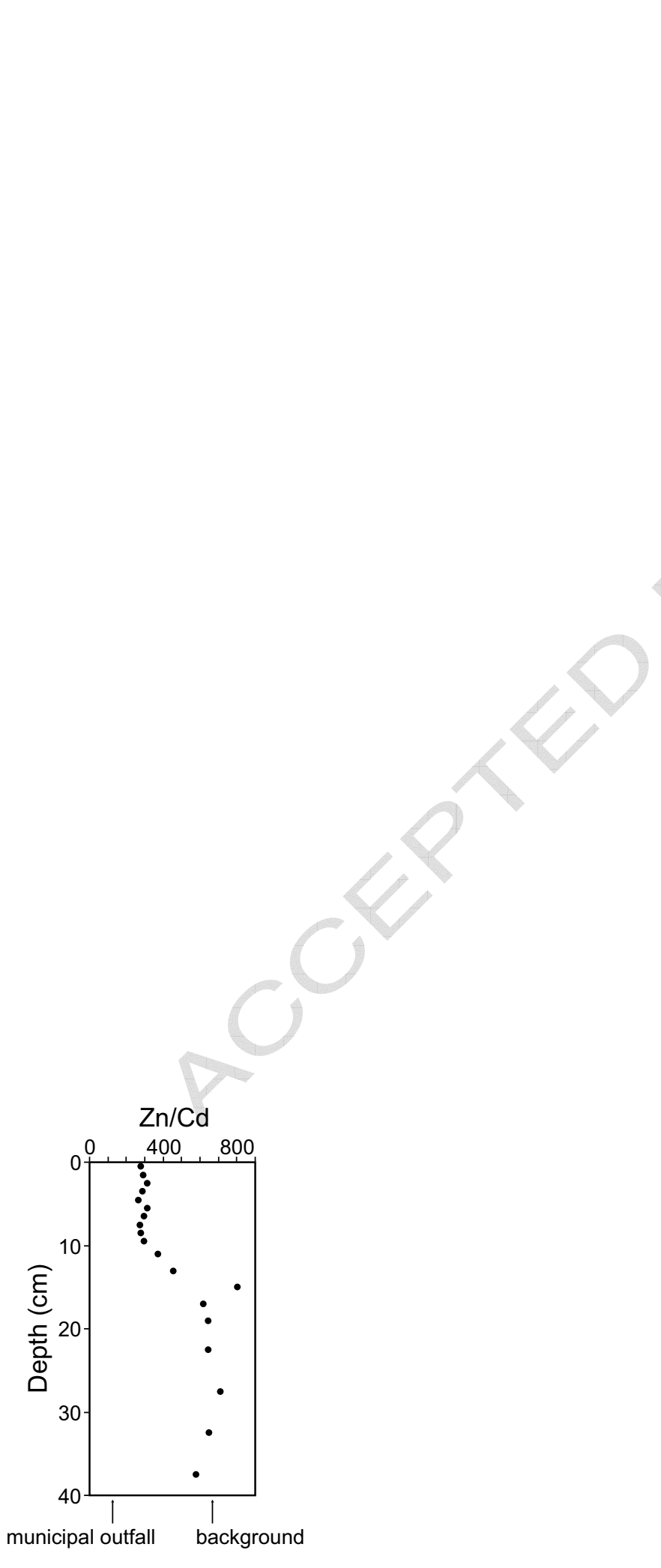

Figure 5

\section{(x)}

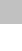

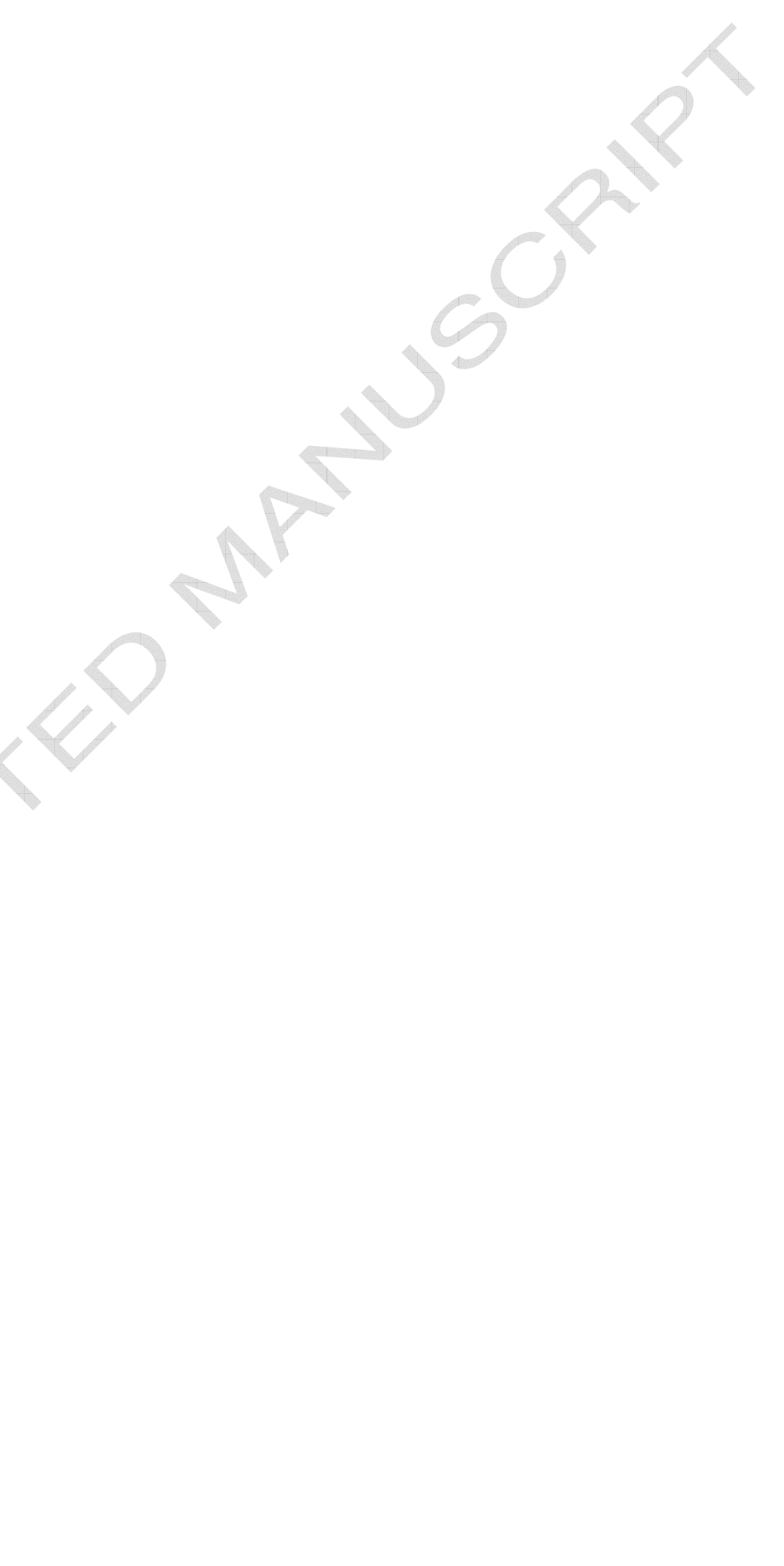

- 